\title{
Influence of Forward Osmosis (FO) membrane properties on dewatering of molasses distillery wastewater
}

\author{
Singh, N.; Petrinic, I.; Hélix-Nielsen, Claus; Basu, S.; Balakrishnan, M
}

Published in:

Journal of Water Processing Engineering

Link to article, DOI:

10.1016/j.jwpe.2019.100921

Publication date:

2019

Document Version

Peer reviewed version

Link back to DTU Orbit

Citation (APA):

Singh, N., Petrinic, I., Hélix-Nielsen, C., Basu, S., \& Balakrishnan, M. (2019). Influence of Forward Osmosis (FO) membrane properties on dewatering of molasses distillery wastewater. Journal of Water Processing Engineering, 32, [100921]. https://doi.org/10.1016/j.jwpe.2019.100921

\section{General rights}

Copyright and moral rights for the publications made accessible in the public portal are retained by the authors and/or other copyright owners and it is a condition of accessing publications that users recognise and abide by the legal requirements associated with these rights.

- Users may download and print one copy of any publication from the public portal for the purpose of private study or research.

- You may not further distribute the material or use it for any profit-making activity or commercial gain

- You may freely distribute the URL identifying the publication in the public portal 


\section{Highlights}

- Distillery wastewater was dewatered using three forward osmosis (FO) membranes

- $3 \mathrm{M} \mathrm{MgCl}_{2} \cdot 6 \mathrm{H}_{2} \mathrm{O}$ draw solutions resulted in a stable flux for all membranes

- COD, melanoidins and antioxidants content was similar for all membranes

- Flux and cleaning ease of HTI-TFC membrane was best but reverse salt flux was high

\section{Graphical abstract}

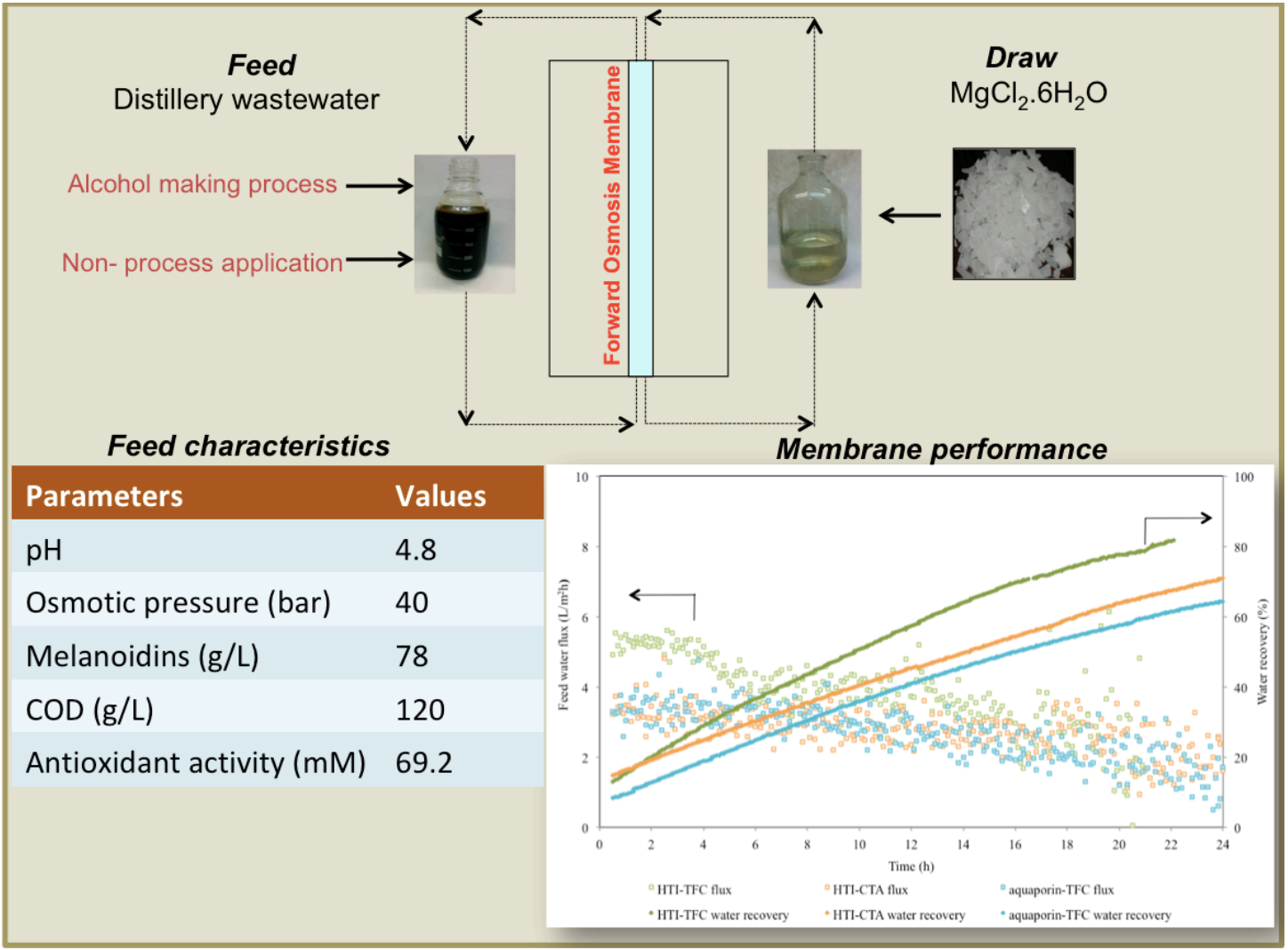




\section{Influence of Forward Osmosis (FO) membrane properties on} dewatering of molasses distillery wastewater

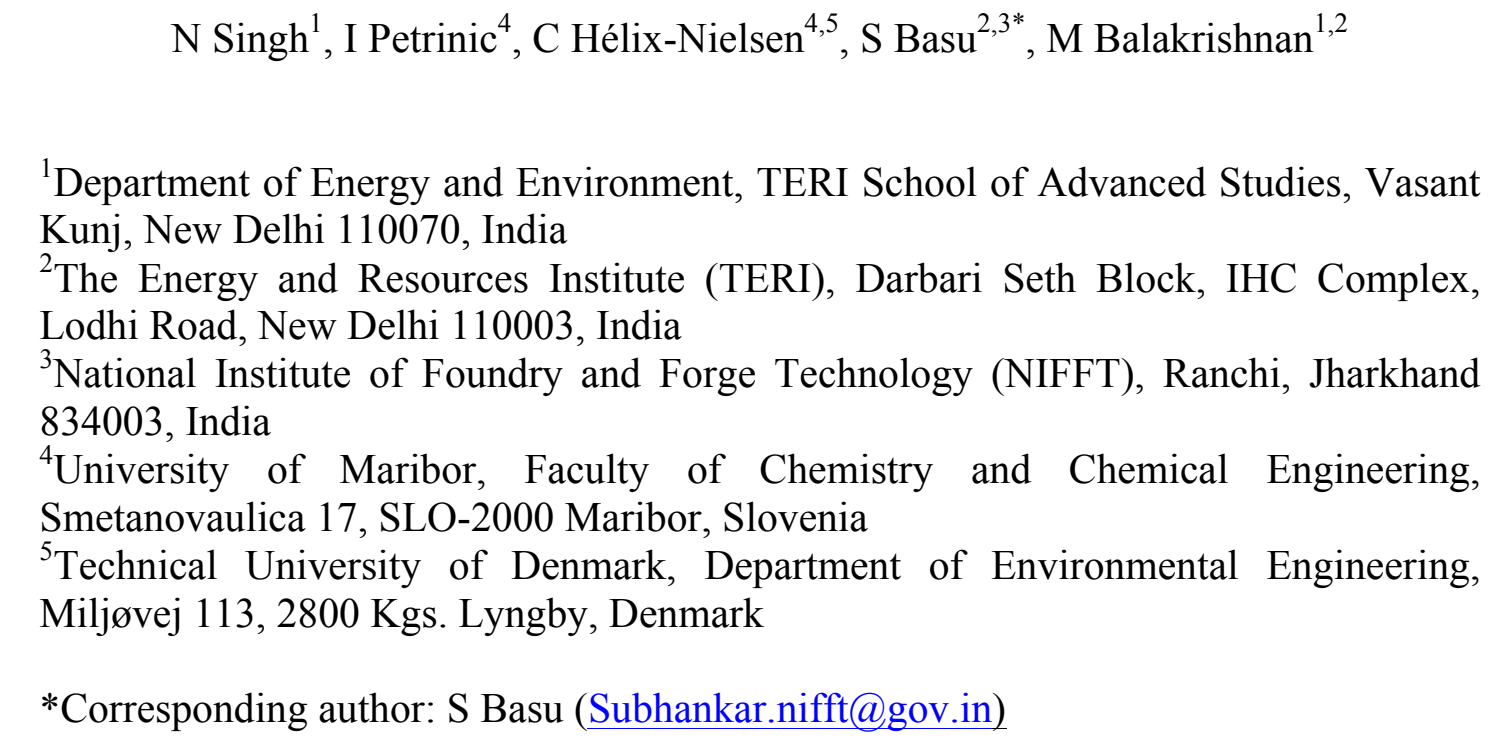

\section{Abstract}

This work presents a comparison of three forward osmosis (FO) membranes viz. HTITFC, HTI-CTA, and aquaporin-TFC for water recovery from a high strength wastewater of sugarcane molasses distillery. Surface properties of the membranes were assessed using scanning electron microscopy (SEM), zeta potential measurement and attenuated total reflection infrared spectroscopy (ATR-IR). A commercial magnesium chloride hexahydrate $\left(\mathrm{MgCl}_{2} \cdot 6 \mathrm{H}_{2} \mathrm{O}\right)(1 \mathrm{M}$ to $4 \mathrm{M})$ solution was used as the draw and a $3 \mathrm{M}$ concentration was identified to be optimal in obtaining stable flux. During a $24 \mathrm{~h}$ FO operation, the average water flux and water recovery respectively were $2.8 \mathrm{~L} / \mathrm{m}^{2} \mathrm{~h}$ and $81 \%$ (HTI-TFC), $2.4 \mathrm{~L} / \mathrm{m}^{2} \mathrm{~h}$ and $71 \%$ (HTICTA) and $1.9 \mathrm{~L} / \mathrm{m}^{2} \mathrm{~h}$ and $66 \%$ (aquaporin-TFC). FO operation over five $24 \mathrm{~h}$ cycles along with membrane physical cleaning after every cycle resulted in water recovery of $82-70 \%$ for HTI-TFC and HTI-CTA membranes and $65-52 \%$ for aquaporin-TFC membrane. The rejection of distillery wastewater components that contribute to the COD, melanoidins and antioxidants content was similar for all the three membranes. Fouling due to deposits on the membrane surface occurred for all membranes but the ease of cleaning was better for HTI-TFC followed by HTI-CTA and aquaporin-TFC membranes. Periodic physical cleaning by water flushing was adequate to remove surface deposits. Overall, HTI-TFC membrane was most suited for concentrating 
37 distillery wastewater, but the effect of high reverse salt flux of this membrane needs 38 to be further investigated.

39

40 Keywords: Forward Osmosis (FO); Membrane properties; Distillery wastewater; 41 Water recovery; Membrane reuse 42 


\section{Introduction}

In engineered forward osmosis (FO) process, a semi-permeable membrane separates the feed and draw solutions. Water from the lower osmotic pressure feed passes through the membrane to the higher osmotic pressure draw, leading to the concentration of the feed and dilution of the draw solutions. FO has been widely studied for desalination and has been extensively used for the treatment of complex wastewater streams such as landfill leachate $[1,2]$, oil and gas exploration wastewater [3-5], olive mill wastewater [6] and digested sludge centrate [7].

The sugarcane molasses based alcohol distillery is a key agro-industrial sector in India. There are presently over 350 units, with an average ethanol production between $30-60 \mathrm{~kL} /$ day [8]. The industry is highly water intensive with a water consumption of 9-21 L/L alcohol and wastewater generation of 7-15 L/L alcohol. The wastewater generated is classified as highly polluting, with chemical oxygen demand (COD) of 80-160 g/L, total dissolved solids (TDS) of $\sim 50 \mathrm{~g} / \mathrm{L}$, dark brown color and the presence of complex organic compounds $[9,10]$. The industry is facing stringent regulations from the Central Pollution Control Board (CPCB) that mandates zero liquid discharge (ZLD); in addition, maximum fresh water consumption of $15 \mathrm{~L} / \mathrm{L}$ alcohol is permitted and the balance demand is to be met by effluent recycling [8]. To comply with these requirements, wastewater treatment by reverse osmosis (RO) and multiple effect evaporation (MEE) are in practice. Although these are established technologies, fouling in RO and scaling in MEE continue to be serious challenges. There is an interest in exploring FO as an alternate treatment for distillery wastewater, due to its low fouling propensity.

The most common commercial FO membranes investigated for various applications include thin film composite (TFC) and cellulose triacetate (CTA) membranes from Hydration Technology Innovations (HTI) and more recently, precommercial Aquaporin Inside ${ }^{\mathrm{TM}}$ membrane (aquaporin-TFC) from Aquaporin A/S

70 [11]. The target is to achieve high permeability and high rejection along with low 71 reverse solute flux. The HTI-TFC membranes have been reported to have superior 72 water permeability and stability over a wider $\mathrm{pH}$ range as compared to the HTI-CTA 73 membranes [12]. With the discovery of aquaporin proteins (also known as water 74 channels) in living cells [13], membranes incorporating aquaporins have been 
prepared. These second-generation biomimetic membranes promise low salt/water permeability ratio $[14,15]$.

The HTI-CTA, HTI-TFC and aquaporin-TFC membranes have been tested extensively for domestic and municipal wastewater treatment [16-18]. For usage in sewage treatment, different CTA flat sheet membranes have been compared [19] and HTI-CTA spiral wound module has been pilot tested for long-term operation with intermittent cleaning [20]. Performance of hybrid FO-membrane bioreactor (FOMBR) with HTI-TFC membrane for treating municipal wastewater has been studied [21]. HTI-TFC and aquaporin-TFC membranes have been compared for removal of trace organics such as atrazine, 2,6-dichlorobenzamide and desthyl-desisopropyl-atrazine [22]. HTI-TFC membranes have also been examined for applications such as phosphorous recovery $[23,24]$, removal of trace organics including pharmaceuticals [25-27] and sludge thickening and dewatering [28]. However, there are no reports comparing different FO membranes in the treatment of complex industrial wastewaters.

In an earlier study, we concentrated synthetic melanoidins (Maillard reaction product) and sugarcane molasses distillery wastewater using aquaporin-TFC membrane [29]. This work goes further to understand whether membrane properties affect the FO performance, including ease of cleaning, for this application. Specifically, two commercial membranes (HTI-TFC and HTI-CTA) and one test membrane (aquaporin-TFC) were characterized and their performance for dewatering distillery wastewater using magnesium chloride hexahydrate $\left(\mathrm{MgCl}_{2} \cdot 6 \mathrm{H}_{2} \mathrm{O}\right)$ draw solution was evaluated.

\section{Materials and methodology}

\subsection{Membranes and their characterization}

TFC and CTA membranes were purchased from HTI, USA. Sample FO membranes (aquaporin-TFC) were gifted by Aquaporin A/S, Denmark. As per manufacturer's instructions, the membrane flat sheets were immersed in water for 30 min prior to use.

Both virgin and fouled FO membranes were characterized. Zeta potential was measured with a SurPASS electrokinetic analyser (Austria) using $1 \mathrm{mM} \mathrm{KCl}$ solution as the electrolyte and polypropylene as the reference membrane. Membrane samples 
of $10 \mathrm{~mm}$ X $20 \mathrm{~mm}$ were fixed on the sample holders using double sided adhesive

109 tape. The gap height in the cell was maintained at $100 \mu \mathrm{m}$. When the electrolyte was

110 passed using hydraulic pressure through the channel between the sample holders, the

111 generated streaming potential (streaming current) was measured by the electrokinetic

112 analyzer. Membrane surface morphology was analysed by scanning electron

113 microscopy (SEM). Air-dried membrane samples were freeze fractured under liquid

114 nitrogen and coated with Pd in an Ar atmosphere. These coated membranes were then

115 mounted to view under a microscope (Zeiss-EVO/MA10, Germany). Using air-dried

116 membrane samples, surface groups were identified using attenuated total reflection

117 Fourier-transform infrared spectroscopy (ATR-FTIR) (IR Affinity 1, FTIR

118 spectrophotometer, Shimadzu). Membrane contact angle was measured using sessile

119 drop technique using the instrument from Tech Inc Ltd. (Chennai, India).

$120 \quad 2.2$ Feed and draw solutions and their analysis

121 Molasses distillery wastewater was collected from an open lagoon in a sugar122 distillery complex in Northern India (Simbhaoli Sugars Limited, Brajnathpur unit, 123 Uttar Pradesh). The wastewater ( $\mathrm{pH} 4.8$, osmotic pressure 40 bar, viscosity $2.09 \pm 0.03$ $124 \mathrm{cP}$, COD $120 \mathrm{~g} / \mathrm{L}$, melanoidins content $78 \mathrm{~g} / \mathrm{L}$, TDS $136 \mathrm{~g} / \mathrm{L}$ ) was used as obtained, 125 without dilution. Osmotic pressure of feed and draw solutions were measured using 126 Gonotec Osmomat 010 freezing point cryoscopic osmometer (Germany) in terms of 127 osmomolarity (osmol/kg). The osmomolarity of the solution was converted to osmotic 128 pressure using modified Morse equation [30]. Because of the inherently high osmotic 129 pressure of the distillery wastewater, magnesium chloride hexahydrate $\left(\mathrm{MgCl}_{2} \cdot 6 \mathrm{H}_{2} \mathrm{O}\right)$ 130 was used as the draw solution. Compared to commonly used $\mathrm{NaCl}$ draw solution, the 131 osmotic pressure of $\mathrm{MgCl}_{2} \cdot 6 \mathrm{H}_{2} \mathrm{O}$ solution at the same concentration is significantly 132 higher (Figure $\mathrm{S} 1$ in supplementary sheet). Industrial grade $\mathrm{MgCl}_{2} \cdot 6 \mathrm{H}_{2} \mathrm{O}$ flakes 133 purchased from Advance Chemical Sales Corporation, New Delhi, India were 134 dissolved in deionized water to obtain different concentrations of the draw solution. 135 Elemental analysis of the $\mathrm{MgCl}_{2} \cdot 6 \mathrm{H}_{2} \mathrm{O}$ solution (supplementary sheet Table $\mathrm{S} 1$ ) was 136 performed using Inductively Coupled Plasma Optical Emission Spectrometer (ICP 137 OES) (Perkin Elmer Optima 3300 RL Range: 165-782 nm). All other chemicals were 138 of analytical grade and purchased from Sigma Aldrich, Bangalore, India.

139 Melanoidins content was obtained by measuring color intensity of the wastewater 140 sample at $475 \mathrm{~nm}$ in UV-Visible spectrophotometer (Aquamate, India). The 
141 absorbance obtained at $475 \mathrm{~nm}$ was converted to melanoidins content $(\mathrm{g} / \mathrm{L})$ by using 142 standard plot. For antioxidant activity, decolorization of 2,2'-Azino-bis(3143 ethylbenzthiazoline-6-sulfonic acid) $\left(\mathrm{ABTS}^{+}\right)$radical at $734 \mathrm{~nm}$ was measured for 2 $144 \mathrm{~min}$ in the sample. This gives the Trolox equivalent antioxidant capacity (TEAC) in $145 \mathrm{mM}$ [31]. COD was measured using standard method for water and wastewater 146 analysis as per APHA [32].

\subsection{FO experimental set-up and membrane performance}

The experimental set-up is as shown in our previous work [29]. A locally fabricated FO cell with symmetric flow channels and working area of $0.0043 \mathrm{~m}^{2}$ was used. All experiments were performed in duplicate using fresh membranes, with active side facing the feed. Feed and draw solutions, both at a flow rate of $1 \mathrm{~L} / \mathrm{min}$, were circulated in counter-current direction. The container of feed solution (either deionized water or distillery wastewater) was placed on an analytical weighing balance (A\&D Japan) connected to a computer and the change in weight was automatically captured by WinCT software. The draw solution container was placed on a magnetic stirrer and continuously stirred at $500 \mathrm{rpm}$ to maintain its homogeneity. over $3 \mathrm{~h}$ using deionized water $(0.5 \mathrm{~L})$ as feed and $1 \mathrm{M} \mathrm{MgCl}_{2} \cdot 6 \mathrm{H}_{2} \mathrm{O}(2 \mathrm{~L})$ as draw.

159 The relatively large draw volume was used to maintain constant osmotic pressure for 160 the duration of the FO experiment.

161 The water flux $\left(\mathrm{J}_{\mathrm{w}}\right)$, reverse salt flux $\left(\mathrm{J}_{\mathrm{s}}\right)$, water recovery $\left(\mathrm{F}_{\mathrm{c}}\right)$ and rejection $(\mathrm{r})$ was determined as follows:

163

$$
\begin{aligned}
& J_{w}=\frac{\Delta V}{A \times \Delta t} \\
& J_{s}=\frac{C_{t} V_{t}-C_{0} V_{0}}{A \times \Delta t} \\
& F_{c}=\frac{\Delta V}{V_{0}} \times 100 \% \\
& r=\left(\frac{C_{t} V_{t}}{C_{o} V_{o}}\right) X 100 \%
\end{aligned}
$$

164 Where $J_{\mathrm{w}}$ in $\mathrm{L} / \mathrm{m}^{2} \mathrm{~h}$ was calculated by measuring the change in weight of feed at 5 165 min intervals and converting into volume change i.e. $\Delta \mathrm{V}(\mathrm{L})$ of feed, $\mathrm{A}\left(\mathrm{m}^{2}\right)$ is the 166 effective membrane area and $\Delta \mathrm{t}(\mathrm{min})$ is the measuring time interval. $\mathrm{J}_{\mathrm{w}}$ and $\mathrm{F}_{\mathrm{c}}$ was 167 calculated for each $5 \mathrm{~min}$ time interval and average value was reported. 
168 Simultaneously, conductivity of deionized water as feed solution was recorded using

169 a $1 \mathrm{mS} / \mathrm{cm}$ probe (Acmas Technology, India). The conductivity value was converted 170 into total dissolved solids (TDS) using a standard plot of 1-25 g/L $\mathrm{MgCl}_{2} \cdot 6 \mathrm{H}_{2} \mathrm{O}$. Thus,

$171 \mathrm{~J}_{\mathrm{s}}$ in $\mathrm{g} / \mathrm{m}^{2} \mathrm{~h}$ was calculated by substituting $\mathrm{V}_{0}, \mathrm{~V}_{\mathrm{t}}$ as volume of the feed solution in $\mathrm{L}$ at 172 time $=0$ and time $=\mathrm{t}$ in $\mathrm{h}$ respectively. $\mathrm{C}_{\mathrm{o}}, \mathrm{C}_{\mathrm{t}}$ are the salt $/$ organic components 173 concentrations of feed solution in $\mathrm{g} / \mathrm{L}$ at time $=0$ and time $=\mathrm{t}$ in $\mathrm{h}$ respectively. $\mathrm{J}_{\mathrm{s}}$ and $174 \mathrm{r}$ was calculated based on bulk concentrations and volumes at the beginning and end 175 of the FO run. Reverse salt flux relative to water flux was also calculated as ratio of $\mathrm{J}_{\mathrm{s}}$ 176 to $\mathrm{J}_{\mathrm{w}}$ in $\mathrm{g} / \mathrm{L}$. This equation gives the loss of solute to feed side. Water recovery was 177 calculated with distillery wastewater as feed.

178 The variation in water flux with varying draw solution concentration was evaluated 179 by stepping up the draw concentration from $1 \mathrm{M}$ (conductivity $76.1 \mathrm{mS} / \mathrm{cm}$ ) to $4 \mathrm{M}$ 180 (conductivity $133 \mathrm{mS} / \mathrm{cm}$ ) as per the procedure described by Zou and co-workers 181 [33]. Experiments were first conducted with deionized water as the feed. The FO run 182 lasted $60 \mathrm{~min}$ for each draw solution concentration, wherein the first $30 \mathrm{~min}$ was 183 allowed for stabilization followed by flux measurement over the next $30 \mathrm{~min}$. To 184 avoid salt accumulation, the porous support side of the membrane was flushed with 185 deionized water before proceeding to higher draw solution concentration. The 186 flushing was done until the rinse water conductivity reached $0.055 \mathrm{mS} / \mathrm{cm}$ (same as 187 fresh deionized water). Using the same membrane, the procedure (with draw solution 188 concentration from $1 \mathrm{M}$ to $4 \mathrm{M}$ ) was repeated with distillery wastewater as feed to 189 measure the decline in water flux due to foulants present in the real wastewater.

190 Using fresh membrane of each type, long duration (24 h) FO was done with 191 distillery wastewater feed and $3 \mathrm{M} \mathrm{MgCl}_{2} \cdot 6 \mathrm{H}_{2} \mathrm{O}$ draw. Water recovery and rejection 192 of melanoidins, COD and antioxidant activity was analyzed at the conclusion of the 193 experiment. Additionally, corresponding water flux for each type of membrane was 194 measured. After $24 \mathrm{~h} \mathrm{FO}$ with distillery wastewater, the membrane surface was rinsed 195 with $20 \mathrm{~mL}$ deionized water to remove the deposited foulants. The suspension was 196 analyzed for surface charge and particle size using Zetasizer (Nano-ZS, Malvern 197 instruments, UK).

198 The hydraulic resistance of the fouling layer was calculated using the conventional 199 resistance-in- series model adapted for FO [34]: 


$$
\begin{aligned}
& R_{m}=\frac{\Delta \Pi}{\mu J_{w}^{o}} \text { and } R_{t}=\frac{\Delta \Pi}{\mu J_{w}^{\prime}} \\
& R_{t}=R_{m}+R_{f}
\end{aligned}
$$

201 Where $\mathrm{J}^{\circ}{ }_{\mathrm{w}}$ and $\mathrm{J}^{\prime}{ }_{\mathrm{w}}$ in $\mathrm{L} / \mathrm{m}^{2} \mathrm{~h}$ are the water flux with feed of deionized water and distillery wastewater respectively, $\Delta \Pi$ in $\mathrm{Pa}$ is the osmotic pressure difference between the bulk draw and feed solutions, $\mu$ in Pa $\mathrm{s}$ is the viscosity of the permeate, $\mathrm{R}_{\mathrm{m}}\left(\mathrm{m}^{-1}\right)$ and $\mathrm{R}_{\mathrm{f}}\left(\mathrm{m}^{-1}\right)$ are the resistances due to membrane and fouling respectively and $\mathrm{R}_{\mathrm{t}}\left(\mathrm{m}^{-1}\right)$ is the total hydraulic resistance.

\subsection{Long-duration FO with intermittent membrane cleaning}

Cleaning of each of the three FO membranes was evaluated over $120 \mathrm{~h}$ operation divided into 5 cycles (C1-C5) of $24 \mathrm{~h}$ each. Between each cycle, 30 min physical cleaning on both sides of the membrane was done by circulating deionized water at the maximum possible flow rate of $1.8 \mathrm{~L} / \mathrm{min}$. Experiments were done in duplicate

211 with fresh membrane for each $120 \mathrm{~h}$ run.

\section{Results and discussions}

\subsection{Membrane performance with deionized water}

The water flux and reverse salt flux with deionized water as feed and $1 \mathrm{M}$

217 HTI-TFC membrane $\left(8.4 \pm 0.59 \mathrm{~L} / \mathrm{m}^{2} \mathrm{~h}\right)$ is nearly 1.5 times the water flux of the HTI-

218 CTA $\left(4.81 \pm 0.06 \mathrm{~L} / \mathrm{m}^{2} \mathrm{~h}\right)$ and aquaporin-TFC $\left(5.81 \pm 0.03 \mathrm{~L} / \mathrm{m}^{2} \mathrm{~h}\right)$ membranes. The TFC membranes are relatively more hydrophilic with lower contact angle $\left(33.2^{\circ}\right.$ for HTI-

220 TFC and $42.6^{\circ}$ for aquaporin-TFC) than CTA membrane (contact angle of $46.9^{\circ}$ ). 221 Also, the thickness of the non-woven support in HTI-CTA membrane reportedly 222 enhances internal concentration polarization (ICP) and reduces the flux [35]. 223 However, the presence of aquaporins in the aquaporin-TFC membranes did not 224 enhance the water flux as expected; this was attributed to prominent concentration 225 polarization by the divalent draw solution [36]. The ratio of reverse salt flux to water 226 flux $\left(\mathrm{J}_{\mathrm{s}} / \mathrm{J}_{\mathrm{w}}\right)$ of the aquaporin-TFC membrane $(0.06 \pm 0.03 \mathrm{~g} / \mathrm{L})$ was lower than of HTI227 CTA $(0.2 \pm 0.01 \mathrm{~g} / \mathrm{L})$ and HTI-TFC $(0.3 \pm 0.01 \mathrm{~g} / \mathrm{L})$ membranes. This could be due to 228 the selective nature of aquaporin proteins, which allow only water molecules to pass through [14]. A detailed water flux pattern and reverse salt flux of the three membranes is given in Figure S2 of the supplementary sheet. 


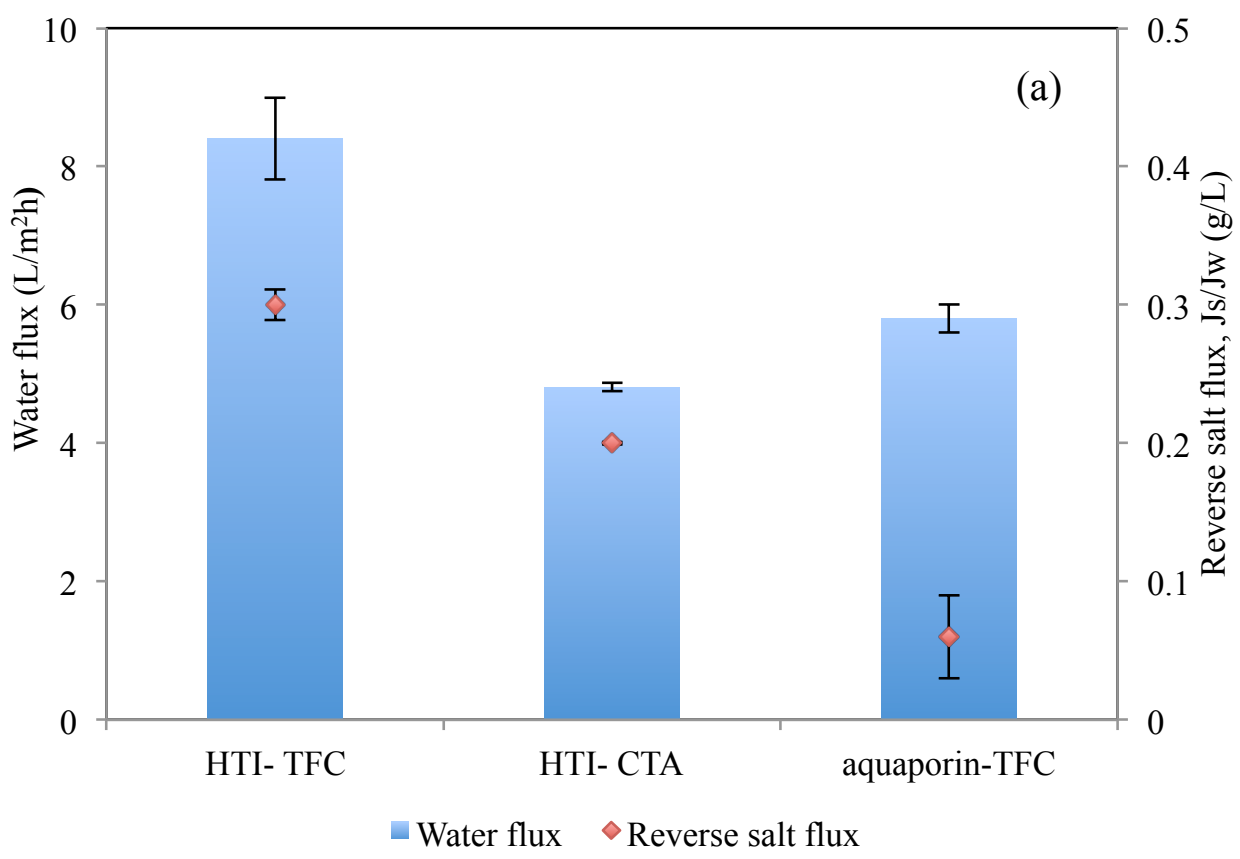

232 Figure 1.Water flux and reverse salt flux of FO membranes with deionized water as 233 feed.

\subsection{Membrane performance with distillery wastewater}

FO water flux was measured for the three membranes by increasing the draw solution concentration from $1 \mathrm{M}$ to $4 \mathrm{M}$ with deionized water feed followed by distillery wastewater feed. The flux profile at each step-up concentration of the draw solution is given in supplementary sheet (Figure S3, S4 and S5). For all the membranes, even at the lowest $\mathrm{MgCl}_{2} \cdot 6 \mathrm{H}_{2} \mathrm{O}$ concentration of $1 \mathrm{M}$, there was significant deviation in the flux between deionized water and distillery wastewater.

242 This drop in flux from the deionized water baseline is attributed to high salinity 243 (conductivity of $42.3 \mathrm{mS} / \mathrm{cm})$ and viscosity $(2.09 \pm 0.03 \mathrm{cP})$ of the wastewater. At 244 lower draw concentrations (up to $0.75 \mathrm{M}$ ), no permeate movement from feed to draw was observed.

246 Figure 2 summarizes the drop in water flux of distillery wastewater feed with the corresponding baseline flux of deionized water for all the three membranes. The drop

248 in flux initially increases with increasing draw concentration but becomes constant 249 thereafter (40-41\% at $2 \mathrm{M}$ and $3 \mathrm{M}$ with HTI-TFC, $48-49 \%$ at $3 \mathrm{M}$ and $4 \mathrm{M}$ with HTI-

$250 \mathrm{CTA}$ and $40 \%$ at $3 \mathrm{M}$ and $4 \mathrm{M}$ with aquaporin-TFC). Beyond a point, increasing the 
251 draw solution concentration (to increase the driving force) does not enhance the flux 252 due to internal and external concentration polarization [37]. This is seen with the HTI253 TFC membrane at $4 \mathrm{M}$ draw concentration. The critical draw solution concentration 254 (a threshold concentration above which fouling in FO occurs) [33] for distillery 255 wastewater is between $2 \mathrm{M}-4 \mathrm{M}$ as the corresponding average flux decline in all three 256 membranes remained in the same range (35-51\%). We also saw in our previous work 257 with aquaporin-TFC membrane [29] that compared to $2 \mathrm{M}$ and $4 \mathrm{M}$ draw solutions, 3 $258 \mathrm{M}$ draw solution displayed stable flux throughout with higher water recovery and 259 higher rejection of COD, melanoidins and antioxidant activity. Based on these results, $2603 \mathrm{M}$ draw concentration was chosen for further experiments with all the membranes.

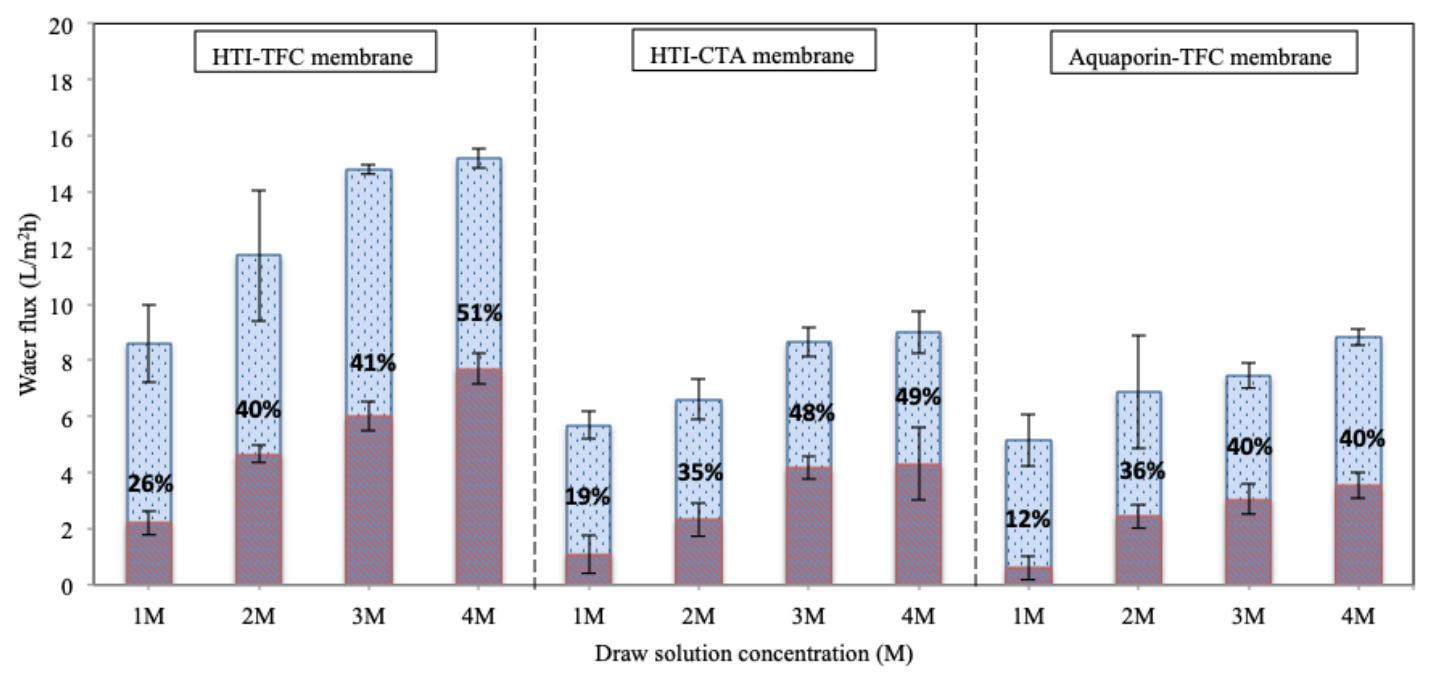

Figure 2. Percentage reduction in water flux of FO membranes at different draw solution concentrations ( $1 \mathrm{M}$ to $4 \mathrm{M}$ ); red bar shows water flux with distillery wastewater as feed, blue bar shows water flux with deionized water as feed.

Figure $3 \mathrm{a}$ shows the water flux and water recovery over $24 \mathrm{~h}$ for all the three membranes. In the first $8 \mathrm{~h}$, the average water flux was $4.66 \mathrm{~L} / \mathrm{m}^{2} \mathrm{~h}, 3.2 \mathrm{~L} / \mathrm{m}^{2} \mathrm{~h}$ and $3.36 \mathrm{~L} / \mathrm{m}^{2} \mathrm{~h}$ for HTI-TFC, HTI-CTA and aquaporin-TFC respectively. After $16 \mathrm{~h}$, average water flux reduced to $3.73 \mathrm{~L} / \mathrm{m}^{2} \mathrm{~h}, 2.7 \mathrm{~L} / \mathrm{m}^{2} \mathrm{~h}$ and $2.74 \mathrm{~L} / \mathrm{m}^{2} \mathrm{~h}$ respectively. With HTI-TFC, because the flux was relatively higher than with the other two membranes, the feed volume reduced to the point that no feed circulation was

274 the experiments (Figure S6 in supplementary sheet), the average water flux was 2.8 $275 \mathrm{~L} / \mathrm{m}^{2} \mathrm{~h}$ (HTI-TFC), $2.4 \mathrm{~L} / \mathrm{m}^{2} \mathrm{~h}$ (HTI-CTA) and $1.94 \mathrm{~L} / \mathrm{m}^{2} \mathrm{~h}$ (aquaporin-TFC). The 
276 average water recovery was 81\% (HTI-TFC), 71\% (HTI-CTA) and 66\% (aquaporin277 TFC) but the average rejection of COD (82-88\%), melanoidins (96-98\%) and 278 antioxidant activity (77-82\%) was similar for all the three membranes (Figure $3 b$ ). 279 Loosely bound deposits were visible on the surface of all the three membranes as 280 discussed further in Section 3.3. The deposits modify the membrane surface 281 characteristics and offer additional hydraulic resistance (as seen in deposits during 282 submerged nanofiltration of molasses fermentation wastewater [38]), causing flux 283 decline as well as restricting the movement of solutes to the draw side. Table 1 284 summarizes the bulk concentration of the distillery wastewater components that 285 contribute to the COD, melanoidins and antioxidants content in the feed over $24 \mathrm{~h}$ 286 FO, along with the final feed volumes for all the membranes.

287

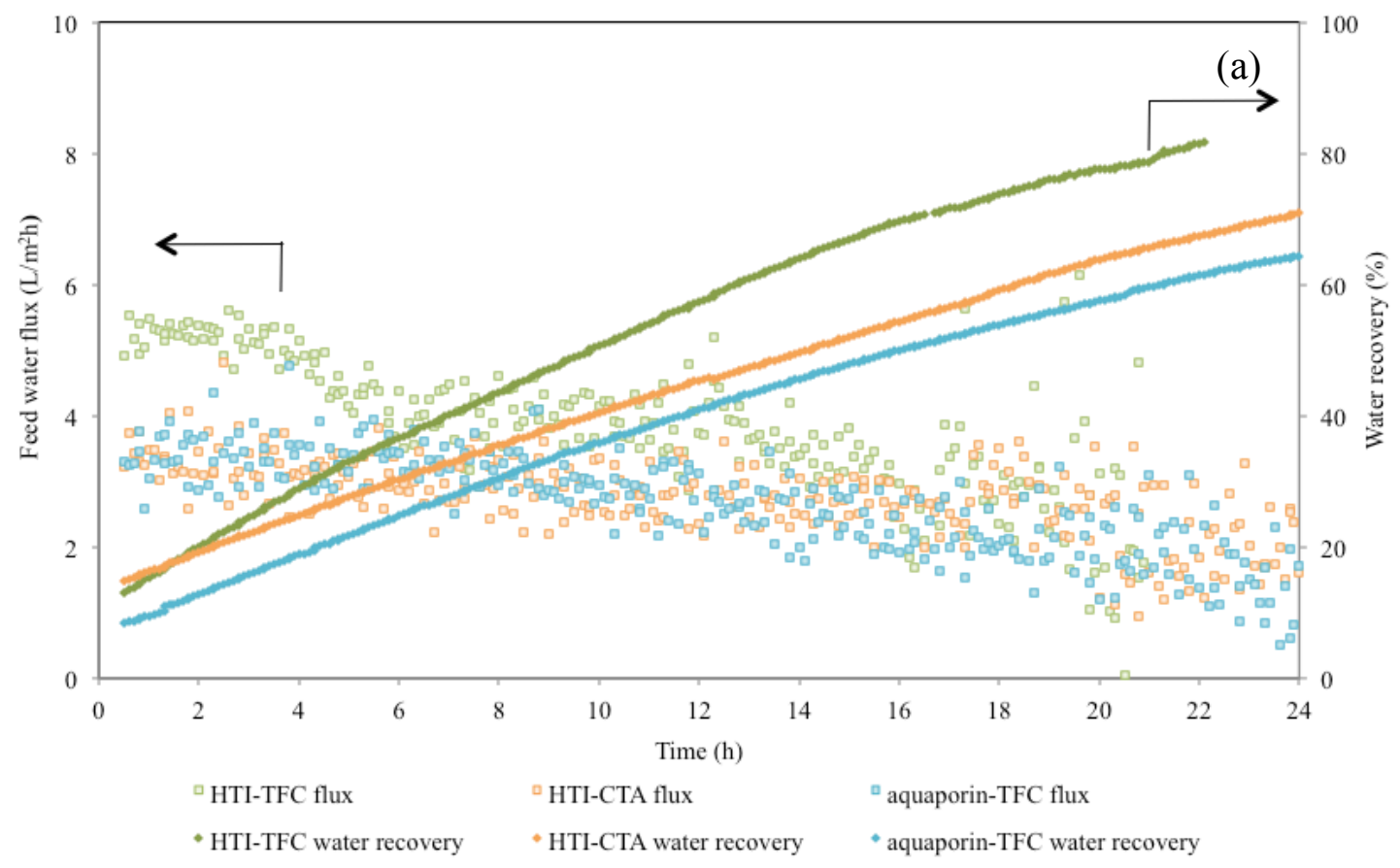




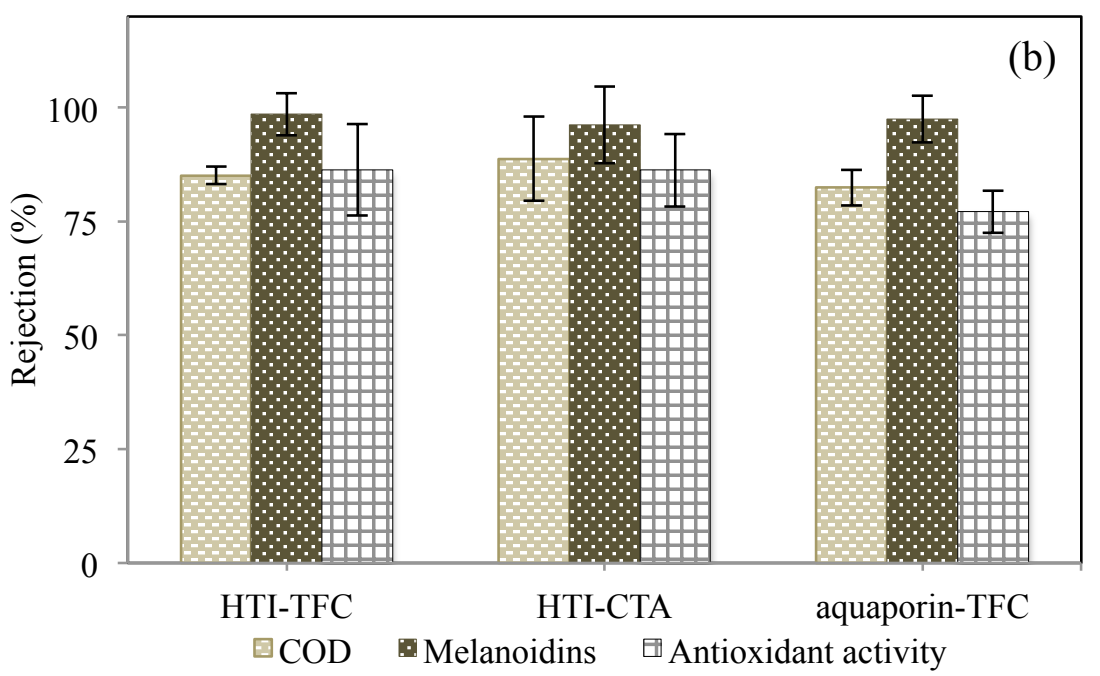

Figure 3. HTI-TFC, HTI-CTA and aquaporin-TFC membranes (a) water flux and

293 water recovery profile (b) rejection of COD, melanoidins and antioxidant activity in

294 distillery wastewater feed with $3 \mathrm{M}$ draw concentration after $24 \mathrm{~h}$ FO.

297 Table 1. Distillery wastewater characteristics before and after FO with different membranes (24 h operation with $3 \mathrm{M} \mathrm{MgCl}_{2} \cdot 6 \mathrm{H}_{2} \mathrm{O}$ draw).

\begin{tabular}{|c|c|c|c|c|c|c|}
\hline \multirow{2}{*}{$\begin{array}{c}\text { FO membrane } \\
\text { type }\end{array}$} & \multicolumn{3}{|c|}{ Initial Parameters ${ }^{*}$} & \multicolumn{3}{|c|}{ Final Parameters } \\
\hline & $\begin{array}{l}\text { COD } \\
(\mathrm{g} / \mathrm{L})\end{array}$ & $\begin{array}{l}\text { Melanoidins } \\
(\mathrm{g} / \mathrm{L})\end{array}$ & $\begin{array}{l}\text { Antioxidant } \\
\text { activity (mM) }\end{array}$ & $\begin{array}{l}\mathrm{COD} \\
(\mathrm{g} / \mathrm{L})\end{array}$ & $\begin{array}{l}\text { Melanoidins } \\
(\mathrm{g} / \mathrm{L})\end{array}$ & $\begin{array}{l}\text { Antioxidant } \\
\text { activity }(\mathrm{mM})\end{array}$ \\
\hline HTI-TFC & \multirow{3}{*}{$106 \pm 14$} & \multirow{3}{*}{$80 \pm 4$} & \multirow{3}{*}{$69 \pm 3$} & $300 \pm 15$ & $267 \pm 8$ & $213 \pm 2$ \\
\hline HTI-CTA & & & & $227 \pm 16$ & $189 \pm 8$ & $155 \pm 2$ \\
\hline aquaporin-TFC & & & & $155 \pm 15$ & $141 \pm 6$ & $102 \pm 7$ \\
\hline
\end{tabular}

"The feed for $\mathrm{FO}$ experiments was taken from the same lot of distillery wastewater and the average is shown. In all experiments, starting feed volume was $0.5 \mathrm{~L}$ that reduced to $0.15 \mathrm{~L}$ (HTI-TFC), $0.20 \mathrm{~L}$ (HTI-CTA) and $0.28 \mathrm{~L}$ (aquaporin-TFC) after $24 \mathrm{~h}$. The final volumes include the system hold-up of approx. $50 \mathrm{~mL}$. All analysis was done in triplicate.

The effect of physical cleaning of the fouled membranes with water flushing at

306 (C1-C5) of $24 \mathrm{~h}$ each with cleaning between cycles. As shown in Figure 4a, all the

307 fresh membranes (C1) showed a steady drop in flux to $1 \mathrm{~L} / \mathrm{m}^{2} \mathrm{~h}$ even though the 308 starting flux for HTI-TFC $\left(6 \mathrm{~L} / \mathrm{m}^{2} \mathrm{~h}\right)$ was higher than for HTI-CTA and aquaporin309 TFC $\left(4.8 \mathrm{~L} / \mathrm{m}^{2} \mathrm{~h}\right)$ membranes. Between the first cleaning (C2) and fourth cleaning 310 (C5), the average water flux was $4.2 \mathrm{~L} / \mathrm{m}^{2} \mathrm{~h}$ (HTI-TFC), $4 \mathrm{~L} / \mathrm{m}^{2} \mathrm{~h}$ (HTI-CTA) and 2.8 $311 \mathrm{~L} / \mathrm{m}^{2} \mathrm{~h}$ (aquaporin-TFC). Water recovery for HTI-TFC and HTI-CTA membranes 
312 remained in the range of $70-82 \%$ but aquaporin-TFC showed a drop from $65 \%(\mathrm{C} 1$, $313 \mathrm{C} 2)$ to $52 \%(\mathrm{C} 3-\mathrm{C} 5)$.The average total resistance $\mathrm{R}_{\mathrm{t}}$ for all the three membranes after $314120 \mathrm{~h}$ is shown in Figure 4b. HTI-CTA and aquaporin-TFC membranes have an 315 inherent higher membrane resistance $\left(\mathrm{R}_{\mathrm{m}}\right)$ of $1.3 \times 10^{16} \mathrm{~m}^{-1}$ compared to HTI-TFC $316\left(0.7 \times 10^{16} \mathrm{~m}^{-1}\right)$. Resistance due to fouling $\left(\mathrm{R}_{\mathrm{f}}\right)$ was as follows: aquaporin-TFC $317\left(0.81 \times 10^{16} \mathrm{~m}^{-1}\right)>\operatorname{HTI}$-TFC $\left(0.65 \times 10^{16} \mathrm{~m}^{-1}\right)>$ HTI-CTA $\left(0.23 \times 10^{16} \mathrm{~m}^{-1}\right)$. The 318 cleaning strategy of water rinsing at higher flow rates between cycles is effective in 319 restoring the water flux for HTI-TFC and HTI-CTA membranes. The flux drop for all 320 membranes is due to fouling because of surface deposits (as discussed in Section 3.3) 321 as well as the increased osmotic pressure of concentrated feed (approximately 70 bar). 322 In this work, both HTI-TFC and HTI-CTA membranes showed surface deposits that 323 were easily removed by water rinsing. Dilutive ICP is also expected to play a role in 324 flux decline because of higher reverse salt flux [39] especially for the HTI-TFC $325(0.3 \pm 0.01 \mathrm{~g} / \mathrm{L})$ and HTI-CTA $(0.2 \pm 0.01 \mathrm{~g} / \mathrm{L})$ membranes. 
(a)
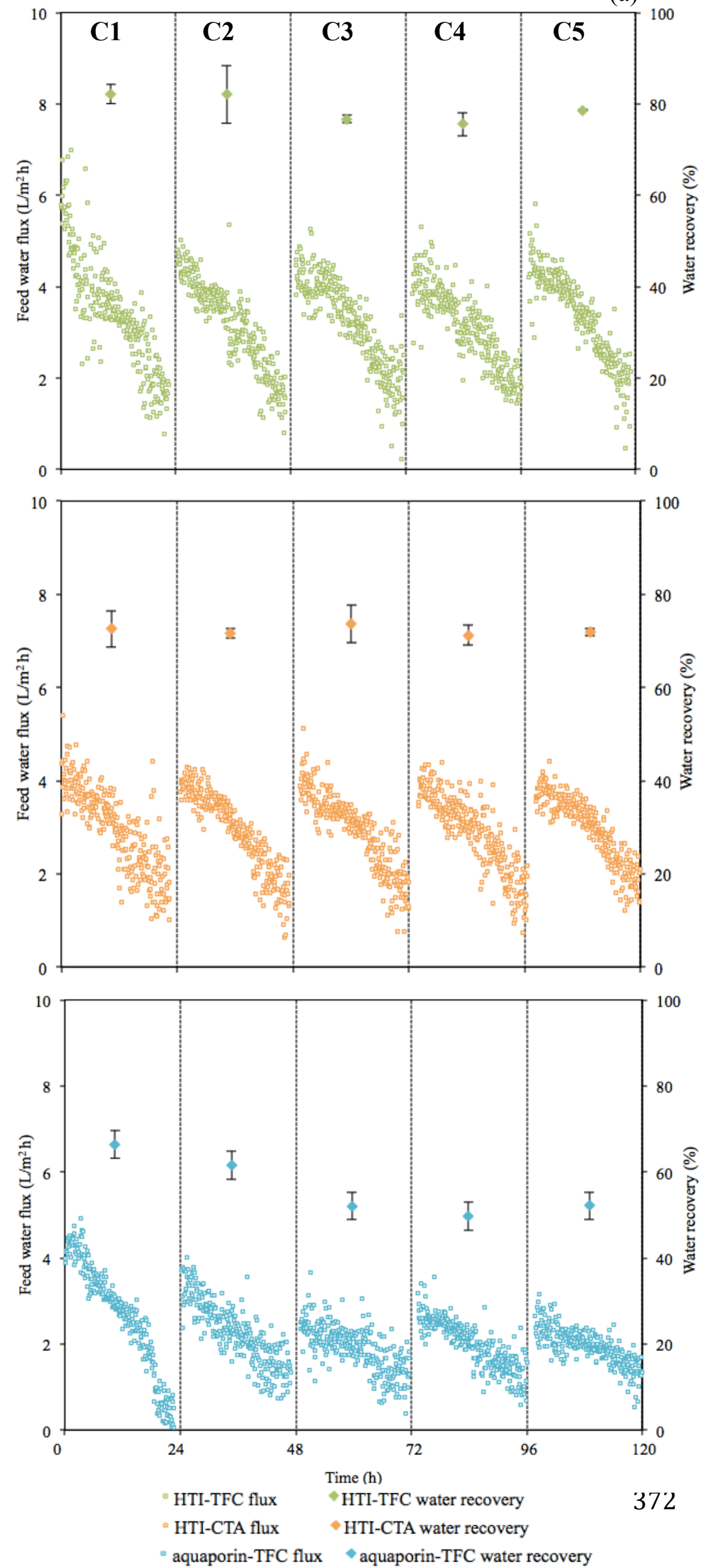

aquaporin-TFC flux $\diamond$ aquaporin-TFC water recovery 


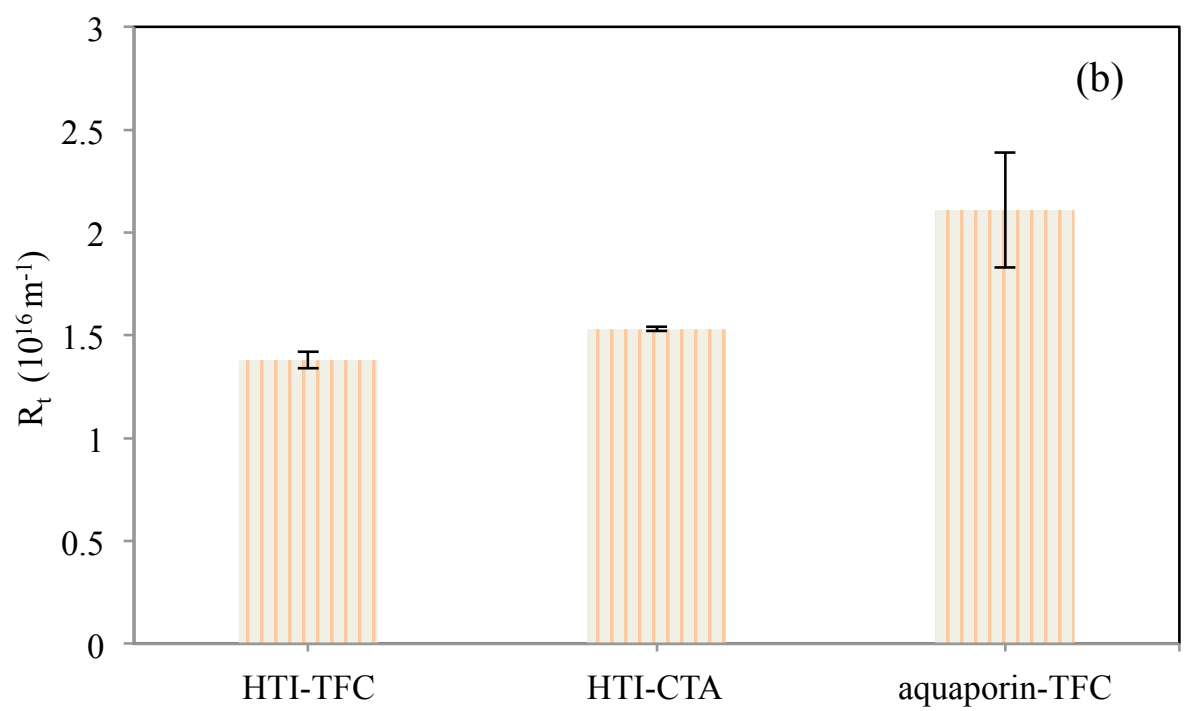

Figure 4. HTI-TFC, HTI-CTA and aquaporin-TFC membranes (a) Performance with intermittent physical cleaning (b) Resistance to filtration (with $3 \mathrm{M}$ draw concentration after $120 \mathrm{~h})$.

\subsection{Membrane interaction with foulants}

Distillery wastewater is characterized by the presence of humic acid, biopolymers such as proteins and carbohydrates along with moieties of Maillard reaction product melanoidins and polyphenols in varied sizes. These molecules have a tendency to form a gel-like layer on the membrane surface [40] which was also observed visually in this study. The deposits on the membrane surface were loosely bound and easily dislodged by soaking the membrane in water. Because of the higher initial flux and corresponding higher water recovery, the deposition was more prominent in HTI-TFC membrane than in the other two membranes. The suspension deposited on the HTITFC membrane after $24 \mathrm{~h}$ FO experiment was collected and analyzed. The average particle size of the deposits was seen to be $1457 \pm 215 \mathrm{~nm}$ (Figure S7 in supplementary sheet) and they possess a negative zeta potential of $-2.49 \mathrm{mV}$ at $\mathrm{pH} 4.4$.

The surface characteristics of the membrane materials were studied to further understand the interaction of the distillery wastewater components with the membrane material. Surface potential measurement indicated the isoelectric points of the three

395 (aquaporin-TFC) showing increasing acidity of the material. The zeta potential at $\mathrm{pH}$ 
membrane at $-77 \mathrm{mV}$ (Figure 5a). When compared to the corresponding virgin membrane, the fouled membrane shows decreasing negative potential with increasing $\mathrm{pH}$. Fouling with distillery wastewater ( $\mathrm{pH} 4.6)$ causes the isoelectric point of all the 400 three membranes to shift towards acidic pH viz. $\mathrm{pH} 3.5$ from $\mathrm{pH} 4.2$ (HTI-TFC), pH 4013.0 from $\mathrm{pH} 3.4$ (HTI-CTA) and $\mathrm{pH} 2.7$ from $\mathrm{pH} 2.9$ (aquaporin-TFC). The 402 corresponding zeta potential at $\mathrm{pH} 7$ increased from $-28 \mathrm{mV}$ to $-32 \mathrm{mV}$ for HTI-TFC, 403 from $-40 \mathrm{mV}$ to $-53 \mathrm{mV}$ for HTI-CTA and from $-78 \mathrm{mV}$ to $-80 \mathrm{mV}$ for aquaporin404 TFC membrane. The net negative charge on the membrane surface (that is maximum 405 in aquaporin-TFC membrane) results in electrostatic repulsion of the anions present in 406 the wastewater. However, as discussed in Section 3.2, solute rejection in this work is 407 similar for all the three membranes, possibly because interaction between foulants and 408 the membrane surface is not a dominant factor affecting solute rejection and 409 corresponding fouling behavior [37].

410 The ATR-FTIR spectrum of the three membranes (Figure $5 \mathrm{~b}$ ) shows the presence 411 of different functional groups on the active layer. The characteristic peak of 412 polyamide is observed in HTI-TFC virgin membrane at $1610 \mathrm{~cm}^{-1}$ due to aromatic 413 ring, which gets masked in the corresponding fouled membrane. A new peak is 414 observed at $2324 \mathrm{~cm}^{-1}$ due to the nitrile $(\mathrm{C} \equiv \mathrm{N})$ group of aromatic compounds present 415 in distillery wastewater. In the fouled HTI-CTA membrane, the aromatic peak at 1610 $416 \mathrm{~cm}^{-1}$ gets masked and a new peak noticed around $1499 \mathrm{~cm}^{-1}$ due to the stretching of 417 the $\mathrm{C}=\mathrm{C}$ group of aromatic compounds. In aquaporin-TFC membranes, no distinct 418 change in the spectra was noticed which corroborates with the marginal change in 419 zeta potential after FO. Figures 5c-h shows SEM micrographs of the three membranes 420 before and after FO of distillery wastewater. The presence of foulants on the 421 membrane surface is clearly visible for all the membranes. The pitted surface on the 422 aquaporin-TFC membrane indicates the presence of aquaporin; at many places the 423 pores are overlaid by the foulants resulting in a smooth surface. 


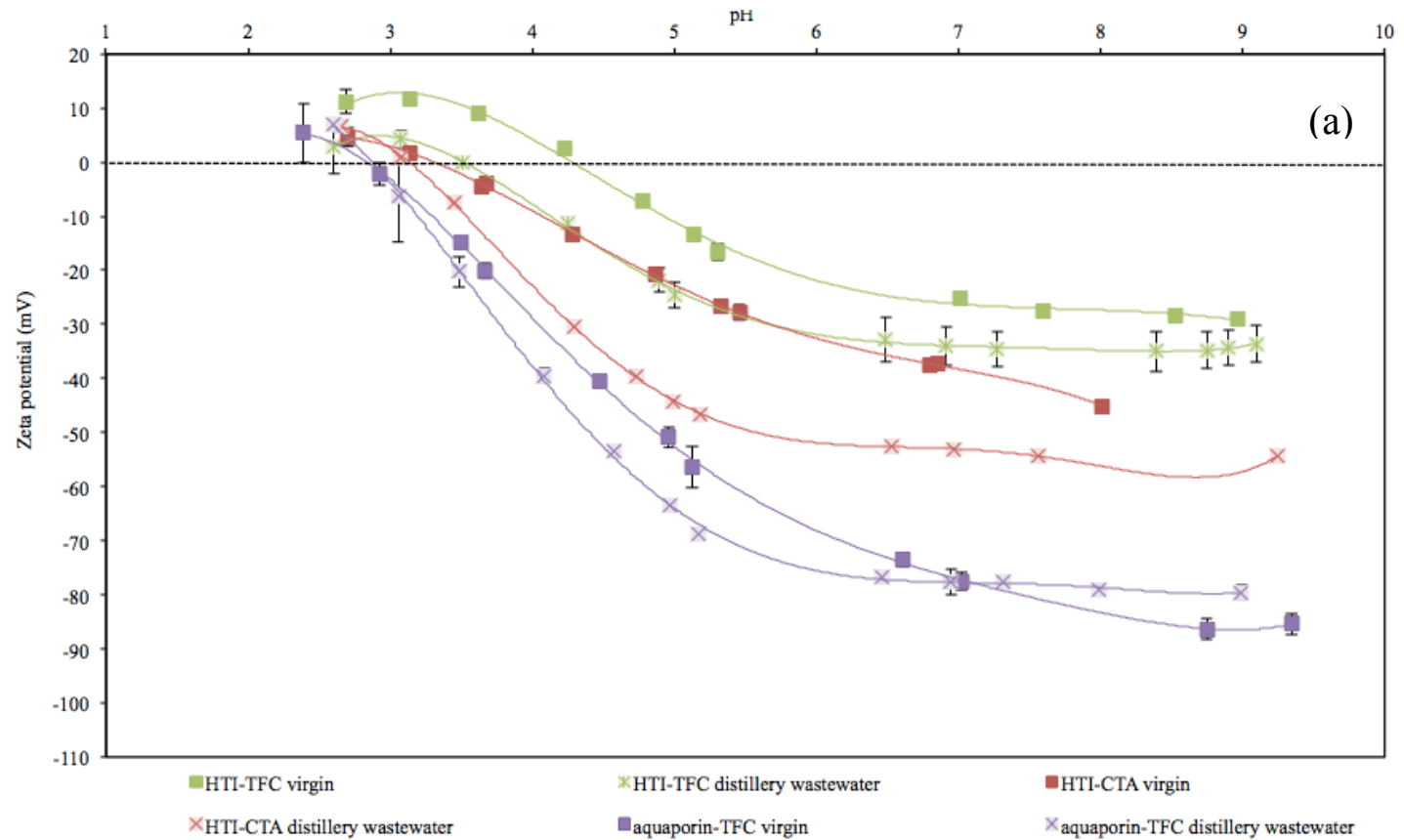

426

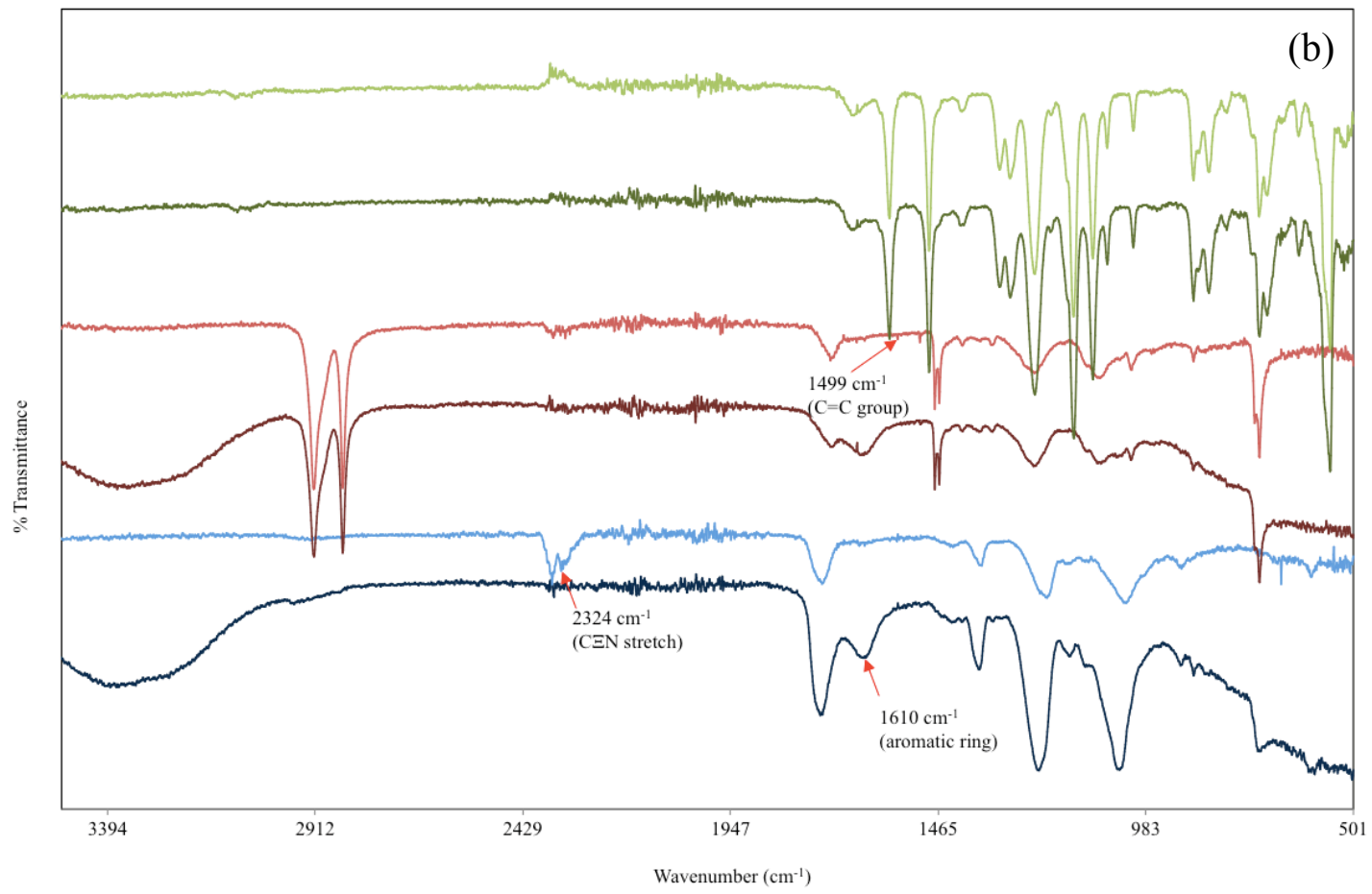

$\begin{array}{lll}- \text { HTI-TFC virgin } & - \text { HTI- TFC distillery wastewater } & \text { HTI-CTA virgin } \\ - \text { HTI- CTA distillery wastewater } & - \text { Aquaporin-TFC virgin } & - \text { Aquaporin-TFC distillery wastewater }\end{array}$



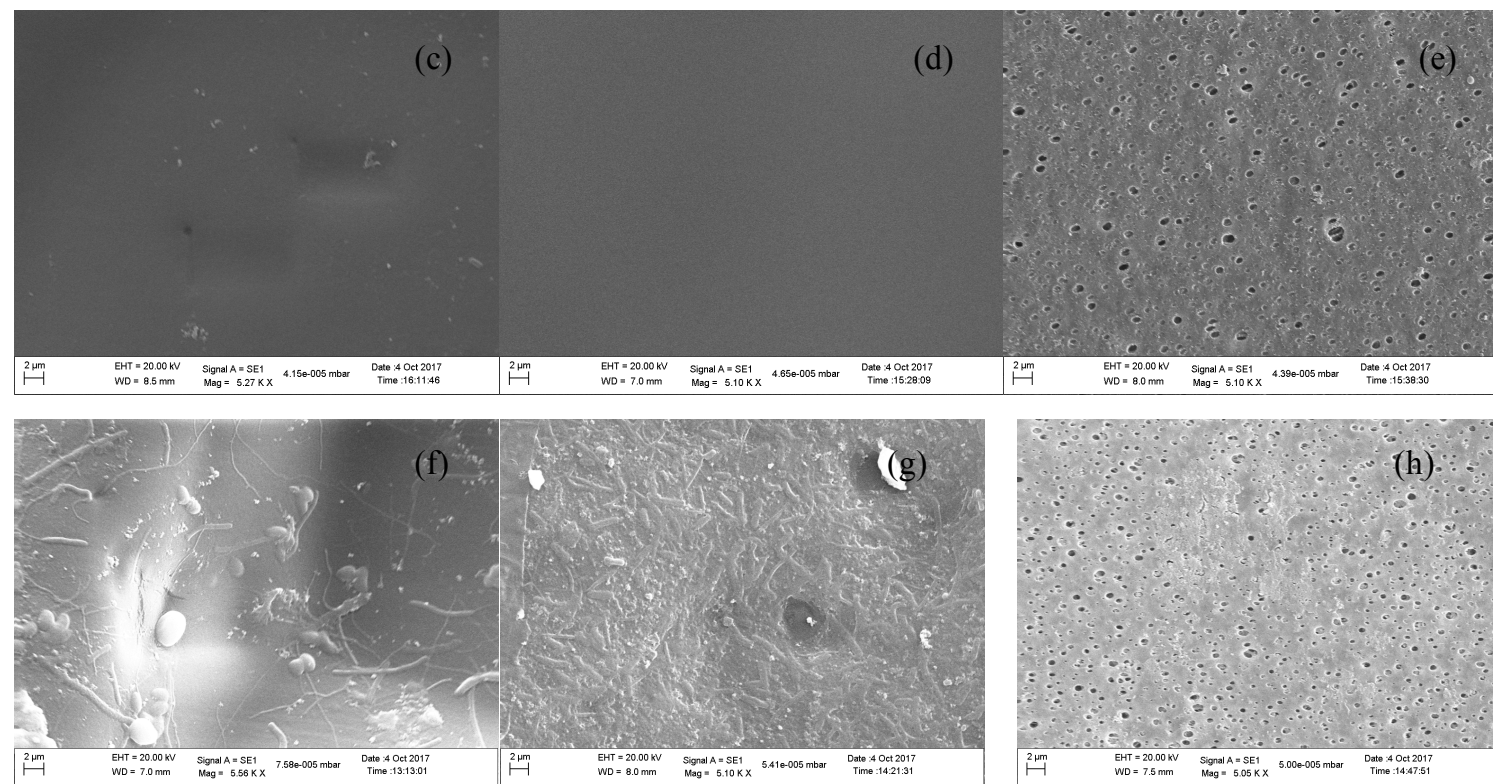

Figure 5. FO membranes HTI-TFC, HTI-CTA and aquaporin-TFC in virgin and fouled state (a) zeta potential (b) FTIR-ATR; SEM images of virgin membranes (c) HTI-TFC (d) HTI-CTA (e) aquaporin-TFC membrane; SEM images of fouled membranes after $120 \mathrm{~h}$ operation (f) HTI-TFC (g) HTI-CTA (h) aquaporin-TFC.

\subsection{Membrane selection for distillery wastewater}

The three FO membranes tested in this study possess different characteristics. The HTI-TFC membrane with the $3 \mathrm{M} \mathrm{MgCl}_{2} \cdot 6 \mathrm{H}_{2} \mathrm{O}$ draw appears to be most suited for treating distillery wastewater overall (Table 2), with higher isoelectric point, less negative zeta potential and low contact angle. The HTI-TFC membrane provides high water flux and recovery and high rejection of organics; additionally the foulants deposited on the membrane surface are easy to dislodge. The drawback is the high reverse salt flux that causes ICP and contributes to flux decline. In this context, aquaporin-TFC membrane may still be a suitable choice due to its low reverse salt flux even though the water flux is lower and the fouled membrane is not easily 443 cleaned with water rinsing alone. A clear trend is observed in this work; however, 444 literature reports [37, 41] suggest there is minimal correlation between membrane 445 properties and foulants properties, and the performance is also influenced by the 446 nature and concentration of the draw solution used. This aspect needs to be 447 investigated further for this application.

448 In this application, freshwater could be obtained from the diluted draw solution using reverse osmosis (RO) and nanofiltration (NF) [42]. Compared to state-of-the art 
technologies such as MEE and RO being used for distillery wastewater treatment, FO

451 offers several advantages. Multi stage membrane filtration costs less than evaporation as observed in concentrating corn-based stillage [40]. FO results in higher water recovery and retention of organic solutes than RO [43]. Membrane fouling coupled with investment and operational cost for high pressure pump in $\mathrm{RO}$ of industrial wastewater reduces the process efficacy and increases the treatment cost [44]. FO followed by RO is reported to be economical and efficient to reduce both operational and capital expenditure of seawater desalination [44]. Thus distillery wastewater concentration by FO followed by freshwater recovery from the diluted $\mathrm{MgCl}_{2} \cdot 6 \mathrm{H}_{2} \mathrm{O}$ draw solution by NF/RO merits further investigation.

460

Table 2. Comparison of tested FO membranes for distillery wastewater concentration with $\mathrm{MgCl}_{2} \cdot 6 \mathrm{H}_{2} \mathrm{O}$ draw solution (rated 1-3 among the three membranes tested, with

464 the best for a parameter rated 1).

\begin{tabular}{lccc}
\hline Parameters & HTI-TFC & HTI-CTA & aquaporin-TFC \\
\hline Deionized water flux & 1 & 3 & 2 \\
Reverse salt flux & 3 & 2 & 1 \\
Water recovery from distillery & 1 & 2 & 3 \\
wastewater & 1 & 1 & 1 \\
Rejection of COD, melanoidins, & & & \\
antioxidant activity from distillery & & & 3 \\
wastewater & 1 & 1 & \\
Ease of cleaning by water rinsing after & & & \\
distillery wastewater FO & & & \\
\hline
\end{tabular}

4. Conclusions

- Among the three FO membranes tested for distillery wastewater feed using $\mathrm{MgCl}_{2} \cdot 6 \mathrm{H}_{2} \mathrm{O}$ as draw, the water flux of HTI-TFC is superior compared to HTI-CTA and aquaporin-TFC membranes. However, the high reverse salt flux of HTI-TFC membrane could be a limitation in long-term operation and needs to be investigated further. Here the low reverse salt flux in the aquaporin-TFC membrane may provide an alternative despite the somewhat lower water flux compared to the HTI-TFC membrane. 
- Irrespective of the draw concentration used, water flux with distillery wastewater deviates substantially from the baseline flux with deionized water. So operation at higher draw solution concentration where flux is stable is recommended.

- Though fouling due to deposits on the membrane surface occurs during FO of distillery wastewater, the ease of cleaning depends on the total resistance offered by the membrane during FO process. The resistance offered by the membrane is directly proportional to the recovery of initial flux. Periodic physical cleaning by water flushing is adequate to remove the surface deposits.

\section{Acknowledgements}

The authors gratefully acknowledge support from Department of Science and Technology (DST) and Slovenian Research Agency (ARRS) under the collaborative project grants INT/Slovenia/ P-15/2014 and BI-IN/15-17-001 respectively. CHN also acknowledges support from the Innovation Fund Denmark via the IBISS and MEMENTO projects. NS acknowledges DST, Government of India for financial support vide reference no. SR/WOS-A/ET-56/2016 under Women Scientists Scheme (WOS-A).

\section{References}

1. Coday, B.D., Xu, P., Beaudry, E.G., Herron, J., Lampi, K., Hancock, N.T., Cath, T.Y., 2014. The sweet spot of forward osmosis: treatment of produced water, drilling wastewater and other complex and difficult liquid streams, Desalination 333, 23- 35.

2. Li, J., Niu, A., Lu, C.J., Zhang, J.H., Junaid, M., Strauss, P.R., Xiao, P., Wang, X., Ren, Y.W., Pei, D.S., 2017. A novel forward osmosis system in landfill leachate treatment for removing polycyclic aromatic hydrocarbons and for direct fertigation, Chemosphere 168, 112-121.

3. Chen, G., Wang, Z., Nghiem, L.D., Li, X.M., Xie, M., Zhao, B., Zhang, M., Song, J., He, T., 2015. Treatment of shale gas drilling flowback fluids (SGDFs) by forward osmosis: Membrane fouling and mitigation. Desalination $366,113-120$.

4. Hickenbottom, K.L., Hancock, N.T., Hutchings, N.R., Appleton, E.W., 
Beaudry, E.G., Xu, P., Cath, T.Y., 2013. Forward osmosis treatment of drilling mud and fracturing wastewater from oil and gas operations, Desalination 312, 60-66.

5. Li, X.M., Zhao, B., Wang, Z., Xie, M., Song, J., Nghiem, L.D., He, T., Yang, C., Li, C., Chen, G., 2014. Water reclamation from shale gas drilling flowback fluid using a novel forward osmosis-vacuum membrane distillation hybrid system. Water Sci. Technol. 69, 1036-1044.

6. Gebreyohannes, A.Y., Curcio, E., Poerio, T., Mazzei, R., Profio, G.D., Drioli, E., Giorno, L., 2015. Treatment of olive mill wastewater by forward osmosis, Sep. Purif. Technol. 147, 292-302.

7. Ansari, A.J., Hai, F.I, Price, W.E., Nghiem, L.D., 2016. Phosphorus recovery from digested sludge centrate using seawater-driven forward osmosis. Sep. Purif. Technol. 163, 1-7.

8. GoI, 2014. Report by Principal Scientific Advisor to Government of India, Electronic source: http://psa.gov.in/publications-reports/opportunities-greenchemistry-initiatives-molasses-based-distilleries-2014 (accessed on $3^{\text {rd }}$ January 2016).

9. Arimi, M.M., Zhang, Y., Götz, G., Kiriamiti, K., Geißen, S.U., 2014. Antimicrobial colorants in molasses distillery wastewater and their removal technologies, Int. Biodeter. Biodegr. 87, 34-43.

10. Basu, S., Mukherjee, S., Kaushik, A., Batra, V.S., Balakrishnan, M., 2015. Integrated treatment of molasses distillery wastewater using microfiltration (MF), J. Environ. Manage. 158, 55-60

11. Perry, M., Madsen, S.U., Jørgensen, T., Braekevelt, S., Lauritzen, K., HélixNielsen, C., 2015. Challenges in commercializing biomimetic membranes, Membranes 5, 685-701.

12. Klaysom, C., Cath, T.Y., Depuydt, T., Vankelecom, I.F.J., 2013. Forward and pressure retarded osmosis: potential solutions for global challenges in energy and water supply, Chem. Soc. Rev. 42, 6959-6989.

13. Preston, G. M., Piazza-Carroll, P., Guggino, W.B., Agre, P., 1992. Appearance of water channels in Xenopus oocytes expressing red cell CHIP28 water channel, Science 256, 385-387.

14. Zhao, J., Zhao, X., Jiang, Z., Li, Z., Fan, X., Zhu, J., Wu, H., Su, Y., Yang, D., Pan, F., Shi, J., 2014. Biomimetic and bioinspired membranes: Preparation 
and application, Prog. Polym. Sci. 39, 1668-1720.

15. Tang, C., Wang, Z., Petrinić, I., Fane, A.G., Hélix-Nielsen, C., 2015. Biomimetic aquaporin membranes coming of age, Desalination 368, 89-105. 16. Choi, B.G., Kim, D.I., Hong, S., 2016. Fouling evaluation and mechanisms in a FO-RO hybrid process for direct potable reuse, J. Membr. Sci., 520, 89-98.

17. Zhang, X., Ning, Z., Wang, D.K., Costa, J.C.D., 2014. Processing municipal wastewaters by forward osmosis using CTA membrane, J. Membr. Sci. 468, 269-275.

18. Hey, T., Bajraktari, N., Davidsson, Å., Vogel, J., Madsen, H. T., HélixNielsen, C., la Cour Jansen, J., Jönsson, K., 2017. Evaluation of direct membrane filtration and direct forward osmosis as concepts for compact and energy-positive municipal wastewater treatment, Environ. Technol. 1-13.

19. Ortega-Bravo, J.C., Ruiz-Filippi, G., Donoso-Bravo, A., Reyes-Caniupán, I.E., Jeison, D. 2016. Forward osmosis: Evaluation thin-film-composite membrane for municipal sewage concentration, Chem. Eng. J. 306, 533-536.

20. Wang, Z., Zheng, J., Tang, J., Wang, X., Wu, Z., 2016. A pilot-scale forward osmosis membrane system for concentrating low-strength municipal wastewater: performance and implications, Scientific reports, DOI: $10.1038 /$ srep21653.

21. Qiu, G., Zhang, S., Raghavan, D.S.S., Das, S., Ting, Y.P., 2016. The potential of hybrid forward osmosis membrane bioreactor (FOMBR) processes in achieving high throughput treatment of municipal wastewater with enhanced phosphorus recovery, Water Research 105, 370-382.

22. Madsen, H.T., Bajraktari, N., Hélix-Nielsen, C., Van der Bruggen, B., Søgaard, E.G., 2015. Use of biomimetic forward osmosis membrane for trace organics removal, J. Membr. Sci. 476, 469-474.

23. Huang, L., Lee, D.J., Lai, J.Y., 2015. Forward osmosis membrane bioreactor for wastewater treatment with phosphorus recovery, Bioresour. Technol. 198, 418-423.

24. Xie, M., Nghiem, L.D., Price, W.E., Elimelech, M., 2014. Toward resource recovery from wastewater: phosphorus extraction from digested sludge using hybrid forward osmosis-membrane distillation process, Environ. Sci. \& Technol. Lett.1, 2, 191-195.

25. Xie, M., Price, W.E., Nghiem, L.D and Elimelech, M., 2013. Effects of feed 
and draw solution temperature and transmembrane temperature difference on the rejection of trace organic contaminants by forward osmosis, J. Membr. Sci. $438,57-64$.

26. Hancock, N.T., Xu, P., Heil, D.M., Bellona, C., Cath, T.Y., 2011. Comprehensive bench and pilot-scale investigation of trace organic compounds rejection by forward osmosis, Environ. Sci. Technol. 45, 84838490.

27. Jin, X., Shan, J., Wang, C., Wei, J., Tang, C.Y., 2012. Rejection of pharmaceuticals by forward osmosis membranes, J. Hazard. Mater. 228, 5561.

28. Zhu, H., Zhang, L., Wen, X., Huang, X., 2012. Feasibility of applying forward osmosis to the simultaneous thickening, digestion, and direct dewatering of waste activated sludge, Bioresour. Technol. 113, 207-213.

29. Singh, N., Petrinic, I., Helix-Nielsen, C., Basu, S., Balakrishnan, M., 2018. Concentrating molasses distillery wastewater using biomimetic forward osmosis (FO) membranes, Water Research 130, 271-280.

30. Wilson, A.D., Stewart, F.F., 2013. Deriving osmotic pressures of draw solutes used in osmotically driven membrane processes, J. Membr. Sci. 431, 205-211.

31. Rufián-Henares, J. A., Morales, F. J., 2007. Functional properties of melanoidins: in vitro antioxidant, antimicrobial, and antihypertensive activities, Food Res. Int. 40, 995-1002.

32. APHA, 2012. Standard method for the examination of water and wastewater, $22^{\text {nd }}$ edition, American Public Health Association Press, Washington, DC.

33. Zou, S., Wang, Y.N., Wicaksana, F., Aung, T., Wong, P.C.Y., Fane, A.G., Tang, C.Y., 2013. Direct microscopic observation of forward osmosis membrane fouling by microalgae: Critical flux and the role of operational conditions, J. Membr. Sci. 436, 174-185.

34. Kim, Y., Lee, S., Shon, H.K., Hong, S., 2015. Organic fouling mechanisms in forward osmosis membrane process under elevated feed and draw solution temperatures, Desalination 355, 169-177.

35. Tang, C.Y., Shea, Q., Lay, W.C.L., Wang, R., Fane, A.G., 2010. Coupled effects of internal concentration polarization and fouling on flux behavior of forward osmosis membranes during humic acid filtration. J. Membr Sci., 354, 123-133. 
36. Chun, Y., Qing, L., Sun, G., Bilad, M.R., Fane, A.G., Chong, T.H., 2018. Prototype aquaporin-based forward osmosis membrane: Filtration properties and fouling resistance, Desalination 445, 75-84.

37. Blandin, G., Vervoort, H., Le-Clech, P., Verliefde, A.R.D., 2016. Fouling and cleaning of high permeability forward osmosis membranes, J. Water Process Eng. 9, 161-169.

38. Liu, M., Zhu, H., Dong, B., Zheng, Y., Yu, S., Gao, C., 2013. Submerged nanofiltration of biologically treated molasses fermentation wastewater for the removal of melanoidins, Chem. Eng. J. 223, 388-394.

39. Arkhangelsky, E., Wicaksana, F., Al-Rabiah, A.A., Al-Zahrani, S.M., Wang, R., 2016. Understanding the interaction between biomacromolecules and their influence on forward osmosis. Desalination 385, 12-23.

40. Arora, A., Seth, A., Dien, B.S., Belyea, R.L., Singh, V., Tumbleson, M.E., Rausch, K.D., 2011. Microfiltration of thin stillage: Process simulation and economic analysis, Biomass Bioenergy 35, 113-120.

41. Lee, S., Boo, C., Elimelech, M., Hong, S., 2010. Comparison of fouling behavior in forward osmosis (FO) and reverse osmosis (RO), J. Membr. Sci., 365, 34-39.

42. Hilal, N., Al-Zoubi, H., Darwish, N.A, Mohammad, A.W., 2005. Nanofiltration of magnesium chloride, sodium carbonate and calcium sulphate in salt solutions, Sep. Sci. Technol. 40, 3299-3321.

43. Cui, Y., Liu, X.Y., Chung, T.S., Weber, M., Staudt, C., Maletzko, C., 2016. Removal of organic micro-pollutants (phenol, aniline and nitrobenzene) via forward osmosis (FO) process: Evaluation of $\mathrm{FO}$ as an alternative method to reverse osmosis (RO), Water Research 91, 104-114.

44. Prodanović, J.M., Vasić, V.M., 2013. Application of membrane processes for distillery wastewater purification-a review, Desalin. Water Treat. 51, 3325-3334. 
643 The osmomolarity (osmol/ $\mathrm{kg}$ ) of the $\mathrm{MgCl}_{2} \cdot 6 \mathrm{H}_{2} \mathrm{O}$ solutions $(0.5 \mathrm{M}, 1 \mathrm{M}, 2 \mathrm{M}, 3$ $644 \mathrm{M}, 4 \mathrm{M})$ was determined using Gonotec Osmomat 010 freezing point cryoscopic 645 osmometer (Germany).

646

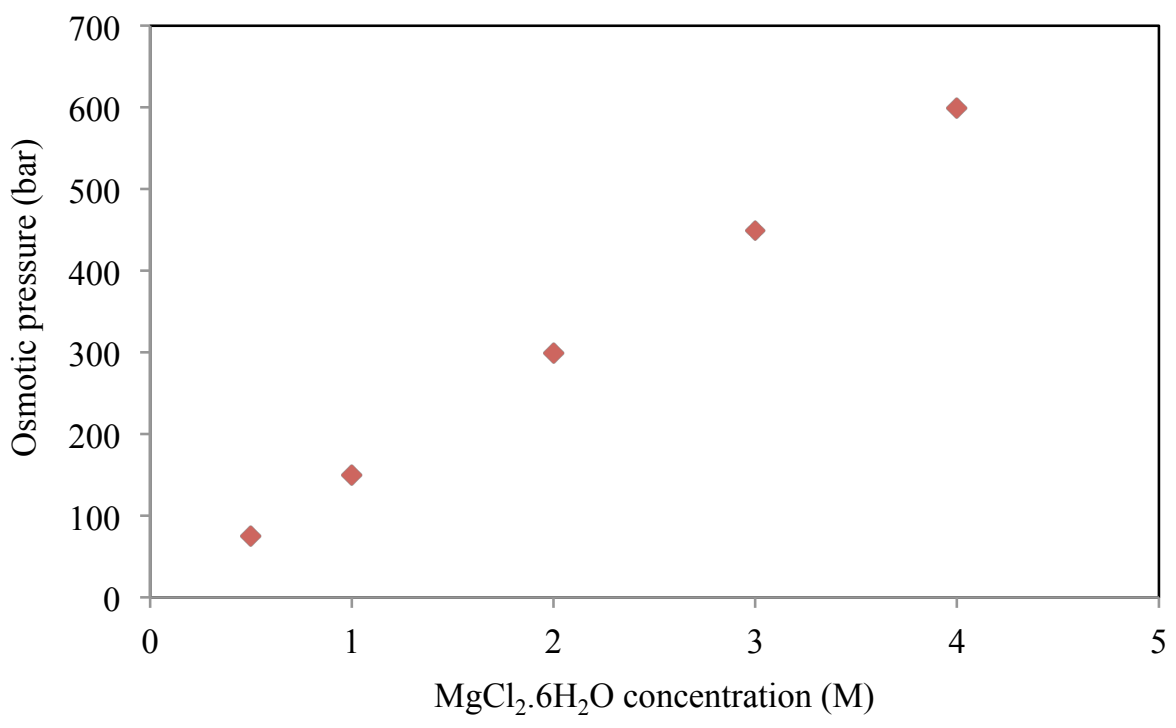

647 Figure S1.Osmotic pressure at different concentrations of $\mathrm{MgCl}_{2} \cdot 6 \mathrm{H}_{2} \mathrm{O}$.

648 
649 Table S1. Elemental analysis of industrial grade $\mathrm{MgCl}_{2} \cdot 6 \mathrm{H}_{2} \mathrm{O}$ used for preparing 650 draw solution

\begin{tabular}{lc}
\hline \multicolumn{1}{c}{ Constituent } & Concentration (mg/L) \\
\hline Magnesium & 73410 \\
Calcium & 406 \\
Potassium & 3636 \\
Boron & 92 \\
Iron & 1.57 \\
Sodium & 3023 \\
Phosphorus & 2.17 \\
Lead & 0.27 \\
Chlorides & 297567 \\
Phosphate & $<0.04$ \\
Nitrate & 32 \\
Sulphate & 3450 \\
Zinc & BDL \\
Copper & BDL \\
\hline
\end{tabular}

651 BDL: Below detection limit

652 


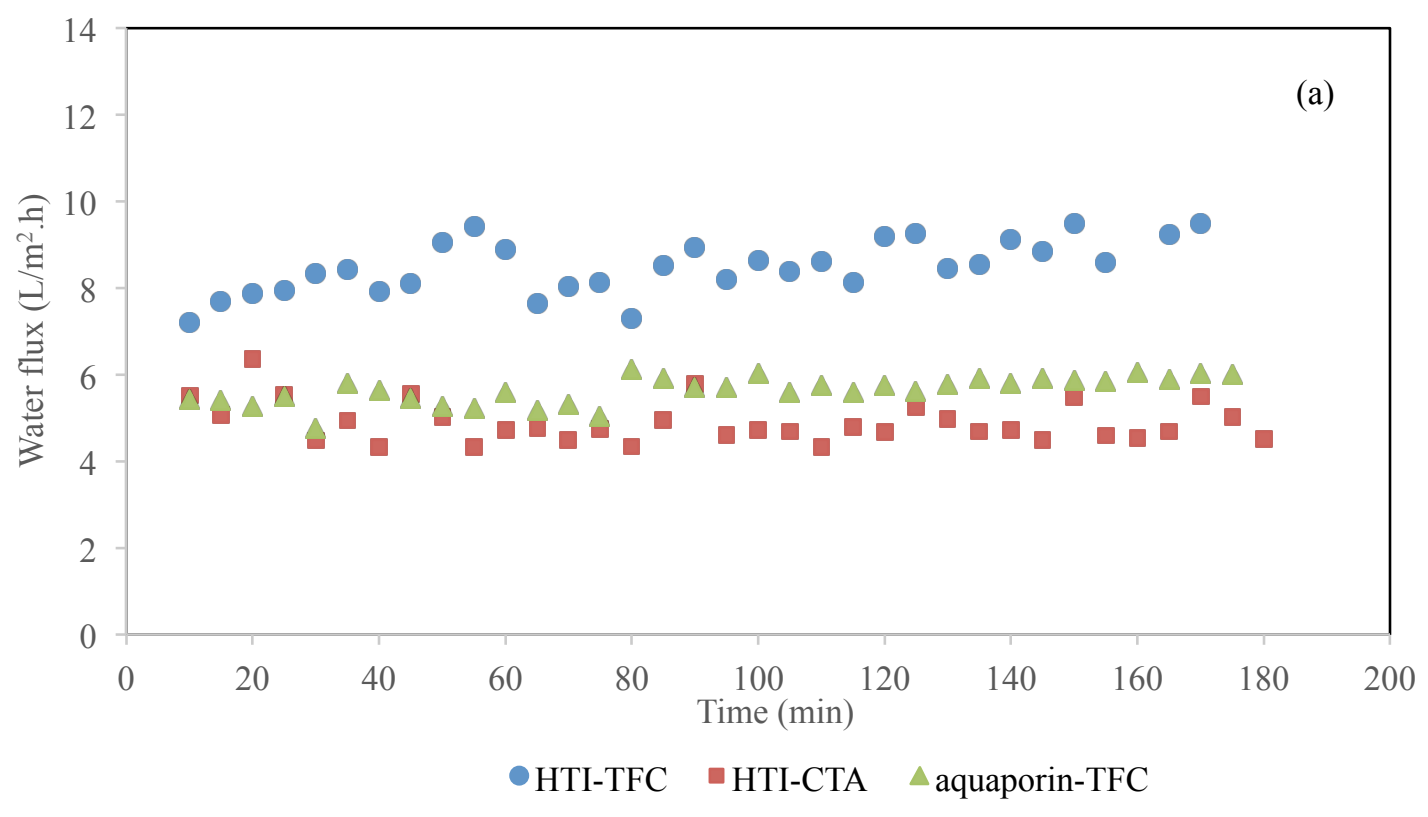

653

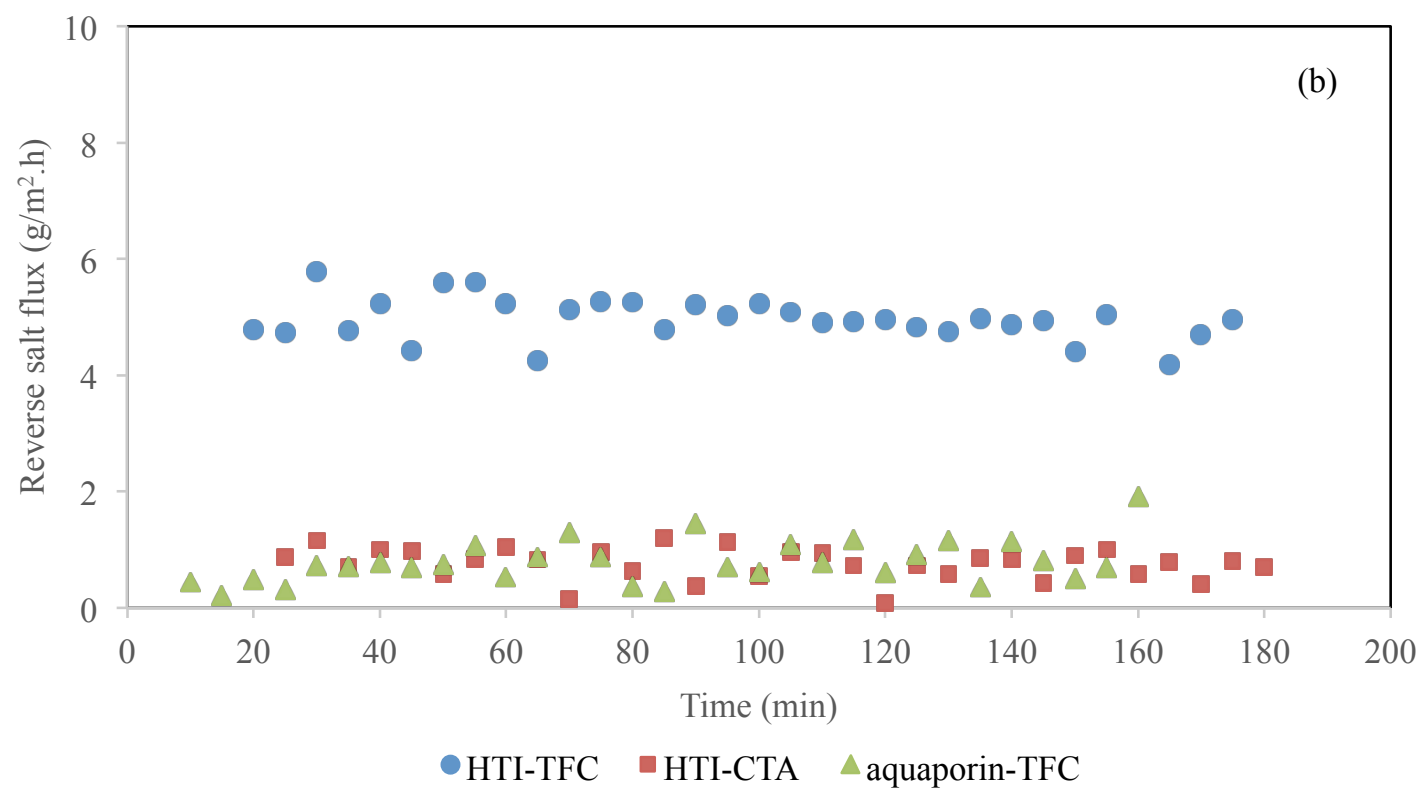

655 Figure S2. Time profile of three FO membranes with deionized water feed and $1 \mathrm{M}$ $656 \mathrm{MgCl}_{2} \cdot 6 \mathrm{H}_{2} \mathrm{O}$ draw solution (a) water flux (b) reverse salt flux. 


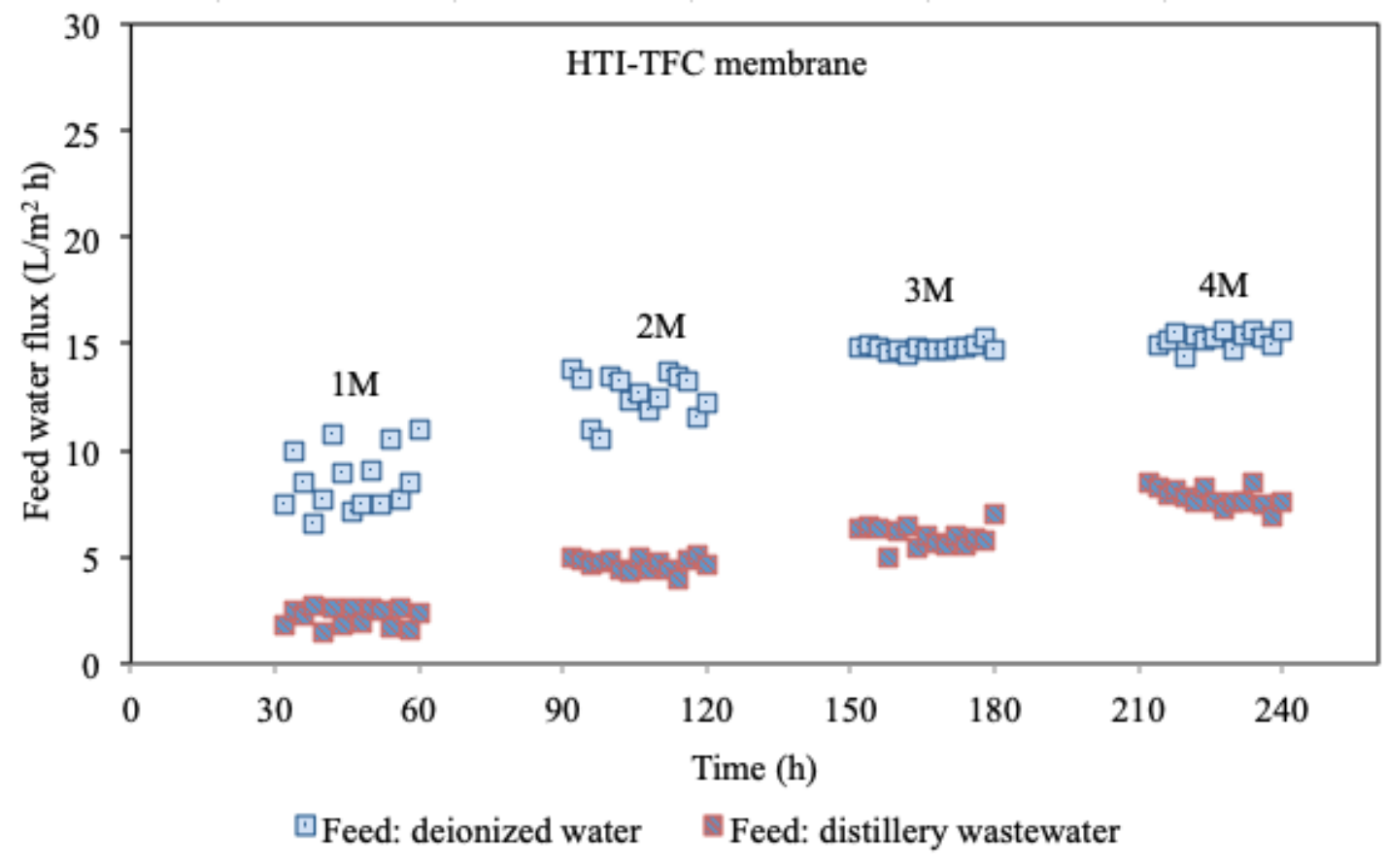

657

658

659 Figure S3. Water flux of HTI-TFC membrane for varying draw solution 660 concentration with deionized water and distillery wastewater feeds.

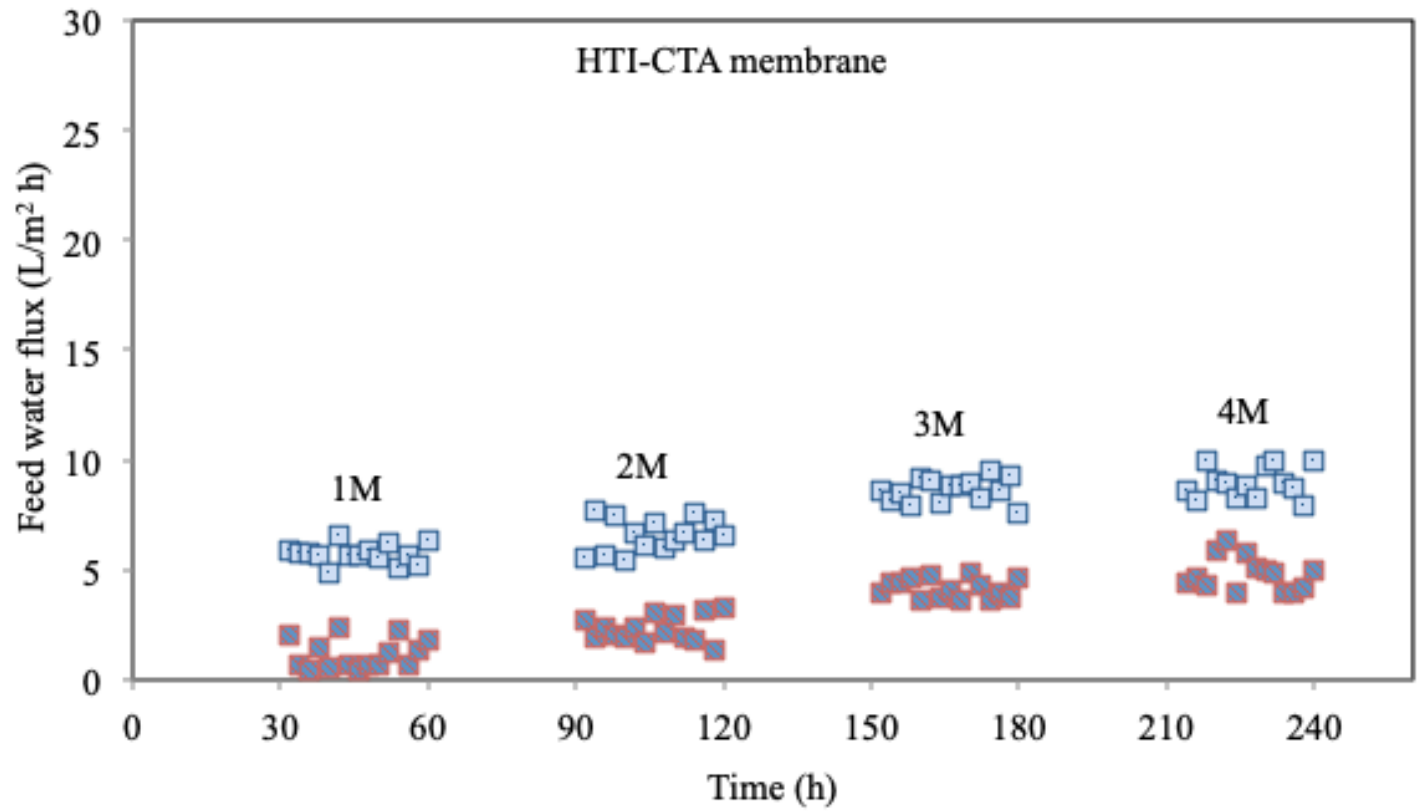

661

$\square$ Feed: deionized water $\quad \square$ Feed: distillery wastewater

662 Figure S4. Water flux of HTI-CTA membrane for varying draw solution 663 concentration with deionized water and distillery wastewater feeds. 


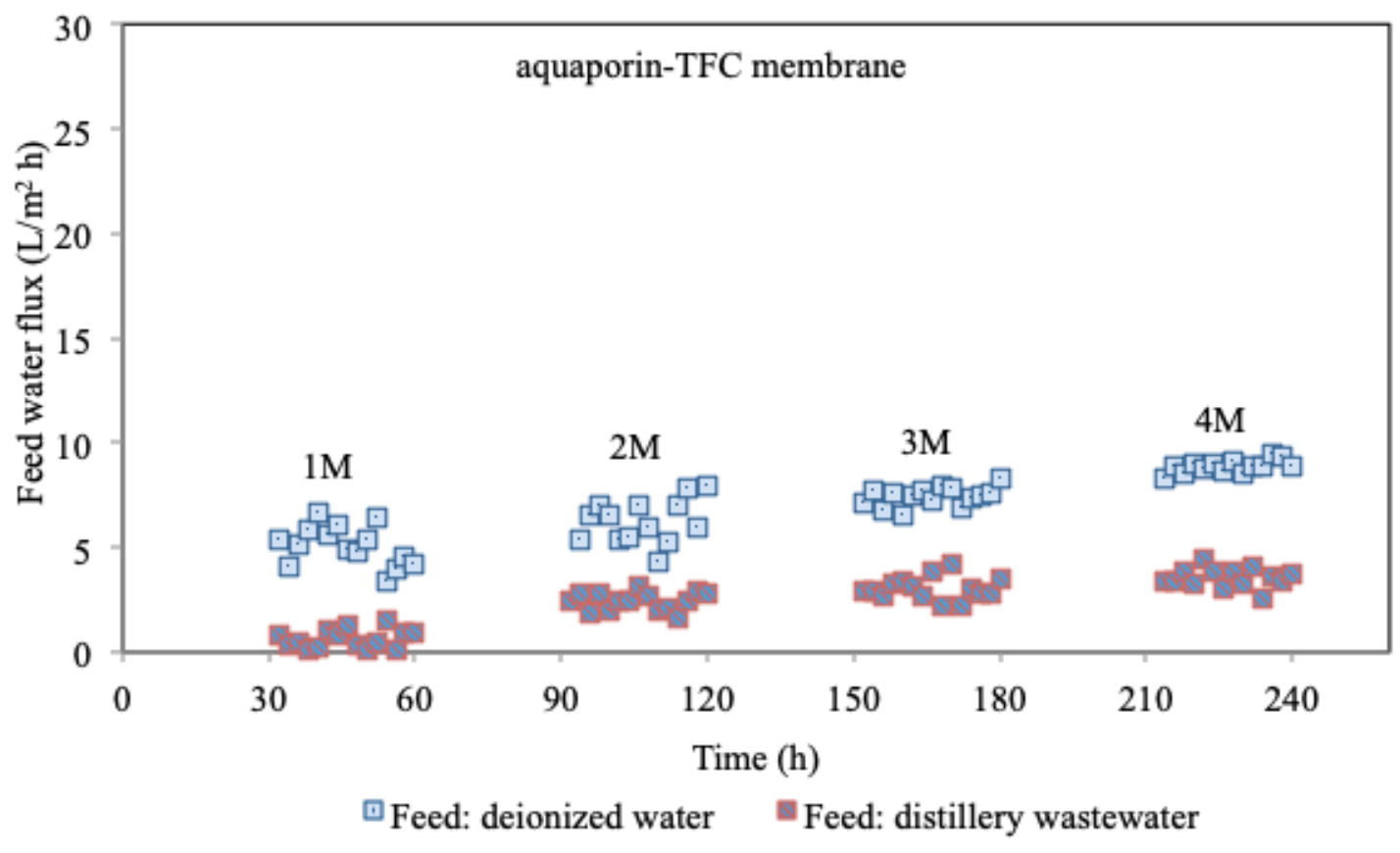

664

665 Figure S5. Water flux of aquaporin-TFC membrane for varying draw solution 666 concentration with deionized water and distillery wastewater feeds.

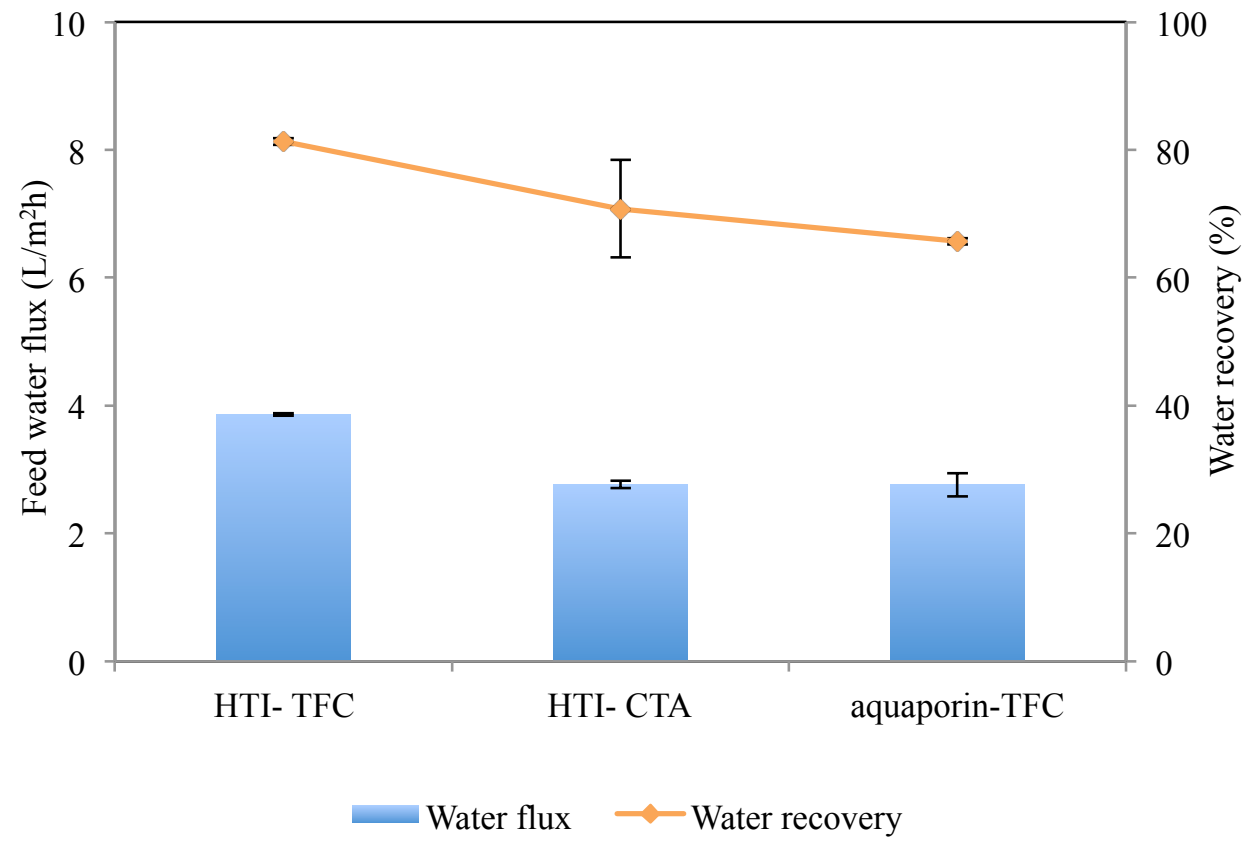

667

668 Figure S6. Average water flux and water recovery after 24 h FO with distillery

669 wastewater feed and $3 \mathrm{M}$ draw solution.

670 


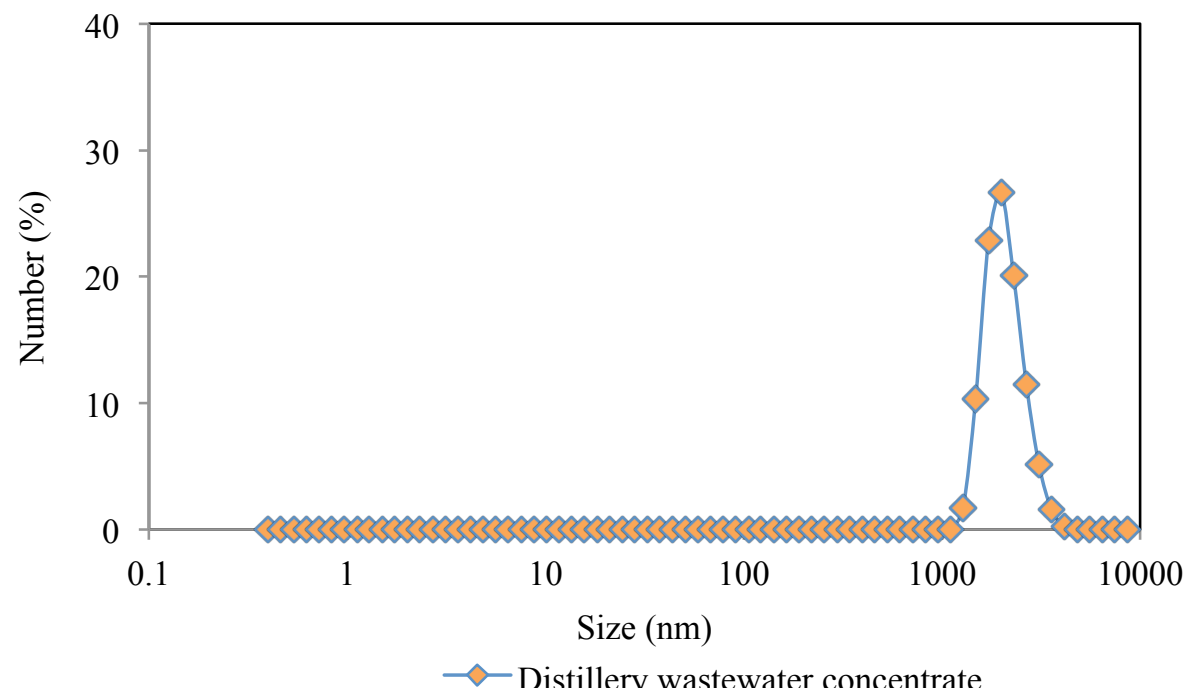

671

672 Figure S7. Particle size distribution of deposits on HTI-TFC membrane surface after 673 distillery wastewater FO.

674 